\title{
Historik umenia Vojtech Tilkovský (1902 - 1978) a jeho pôsobenie na Univerzite Komenského
}

\author{
Katarína BEŇOVÁ
}

\begin{abstract}
Vojtech (Béla) Tilkovský, the art historian, art critic, radio editor and journalist, is not well known among art historians. His primary research focused on painter Dominik Skutezky (Skutecký), about whom he wrote his masters' thesis and dissertation, and in 1954 his monograph. Tilkovský also sought out teaching positions. After several attempts at the Slovak School of Technology in 1955, he became a part-time lecturer of art history at his alma mater (Comenius University). His art research of the $19^{\text {th }}$ century was interrupted several times, first by the Slovak State, the defence of his position within this state and subsequently by a change in the political situation in 1948. Although he could not publish continuously, his publishing activities in Slovakia, Czechia and Hungary are relatively abundant and essential for this period.
\end{abstract}

Keywords: Vojtech Tilkovský, Art History, Comenius University, Skutezký, Art History Seminar, $19^{\text {th }}$ Century

Pre väčšinu odborníkov dejín umenia je osobnost' historika umenia, výtvarného kritika, rozhlasového redaktora a žurnalistu Vojtecha (Bélu) Tilkovského málo známa. Na Filozofickej fakulte Univerzity Komenského (d’alej UK) najprv študoval dejiny umenia a v 50. rokoch 20. storočia tu pôsobil ako externista. Do tohto obdobia pracoval medzi Bratislavou a Prahou až sa následne od roku 1958 natrvalo usadil v českej metropole. Jeho hlavná bádatel'ská činnost' je spojená predovšetkým s osobnost'ou maliara Dominika Skutezkého (Skuteckého), o ktorom napísal nielen diplomovú a dizertačnú prácu, ale predovšetkým vydal v roku 1954 jeho monografiu. ${ }^{1}$ Menej sú známe jeho práce na poli moderného umenia, ktorým sa venoval napríklad v kontexte Tilkovského práce

1 TILKOVSKÝ, V.: Dominik Skutecký. Život a dielo. Bratislava 1954.

2 HUSHEGHYI, G.: Komárom - Kassa - Bécs: „A Szép“ (1923). In: Limes. Társadalom - természet-Történelem. Müvész̨etMüveldödés-Irodalom. Tudományos Szemle, 1999, č. 1, s. 93-106. v mad'arskom prostredí Gabriel Hushegyi. ${ }^{2} \mathrm{~V}$ medzivojnovom období pôsobil ako redaktor časopisu o umení $A$ S zép, ktorý vychádzal v mad’arskom jazyku v Československu. Tilkovský začal svoju kariéru v medzivojnovom období a patril medzi kritikov pôsobiacich na našom území, podobne ako Rezső Szalatnai alebo Kálman Brogányi, ktorí využívali znalost' mad'arského a slovenského jazyka. Podobnú dvojjazyčnost' nachádzame aj u umelcov ako Edmund Gwerk, Eduard Nemes, František Reichentál alebo Imro Weiner Král', pričom s viacerými z nich bol v kontakte i Tilkovský a ich korešpondencia je vedená vždy v mad’arskom jazyku. Jeden z dôležitých maliarov košickej moderny Gejza Szóbel ho v roku 1928/29 portrétoval (obr. 1). ${ }^{3}$

3 Gejza Szóbel: Portrét dr. Tilkovskébo, 1928 - 1929, olej, plátno, 130 x 97 cm, Slovenská národná galéria, inv. č. O 5923. Žiak Karola Harmosa, člen tzv. komárňanského okruhu, ktorý vyštudoval v Budapešti, pôsobil v Komárne, Budapešti, Prahe, kde sa mal možnost' stretnút' is Vojtechom Tilkovským. 


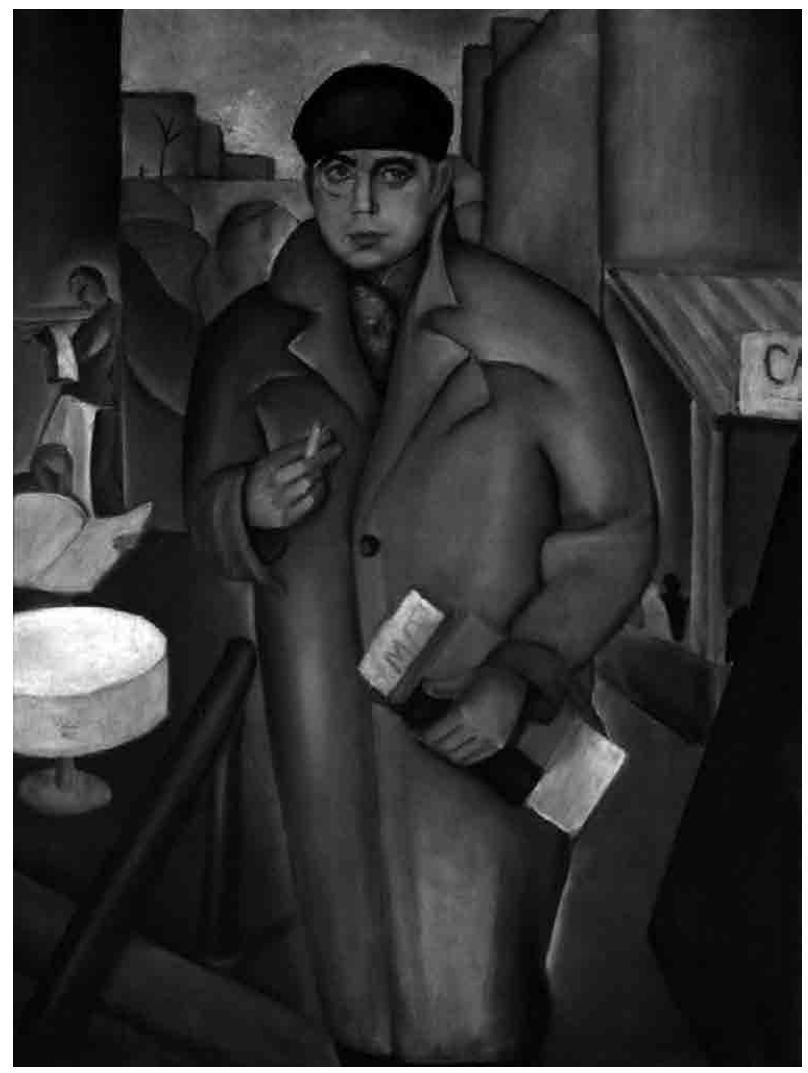

Obr. 1: Gejza Szóbel: Portrét Vojtecha Tilkouskébo, 1928/29. Foto: Slovenská národná galéria.

Ako uviedol v Tilkovského nekrológu jeho kolega a priatel’ Július Kálman, „Rodák z Levoče (1902) pri svojej generačnej príslušnosti zosobnil všetky regionálne danosti Spiša, vrátane znalosti troch rečí, vel'kej usilovnosti, búzevernatosti a presnosti v práci. "A Svoje jazykové znalosti a plynulý prechod medzi slovenským, českým a mad'arským jazykom je citel'ný aj zo zachovaných textov a hlavne korešpondencie tohto kritika a his-

4 KÁLMAN, J.: Vojtech Tilkovský. In: Výtvarný život, 1978, č. 6, s. 6-7.

5 Vojtech Tilkovský (1902 - 1978). Süpis archivneho fondu. Zost. Valéria Hrtánková, Bratislava 1986. V roku 2000 získal archív d'alšie dokumenty od Tilkovského syna. Za pozornost' stojí Osobný fond Tilkovský v archíve RTVS, týkajúci sa jeho činnosti pre rozhlas.

' SCHREIBEROVÁ, J.: Vojtech Tilkovský (monografia), Diplomová práca FiF UK. Bratislava 2016 (neobhájená). torika umenia, ktorá sa nachádza primárne v Archíve výtvarného umenia v Slovenskej národnej galérií. ${ }^{5}$ Posledným pokusom o spracovanie osobnosti Tilkovského v kontexte jeho rôznorodej činnosti bola diplomová práca Vojtech Tilkouský (monografia) od Jany Schreiberovej, ktorá ale ostala neobhájená. ${ }^{6}$

Kto bol Vojtech Tilkovský?

Vojtech Tilkovský pochádzal z Levoče, kde sa narodil 18. augusta 1902 . Zo strany otca pochádzal z levočskej rodiny, matka Izabela rod. Thály bola pôvodom z Komárna. Vo svojom rodisku sa už od detstva stretával s výtvarným umení. Ako sám píše vo svojom životopise, „Zájem o uméní vąbudilo ve mně krásné goticko-renesančni prostredi mého rodiste Levoče. Jǐ̌. jako malý školák mél jsem možnost sledovat sbèratelskou práci Kornela Divalda, jehož trízszuazkový soupis umèleckých památek. Spise byl první odbornou literaturou, kterou jsem studoval. ${ }^{\text {“7 }}$ Do jeho pozornosti sa dostalo súdobé umenie, kedy mal možnost' pozorovat' činnost' mad'arských pleneristov, ktorí počas prvej svetovej vojny pôsobili v Levoči. Na podnet dr. Bélu Lazara, $\mathrm{v}$ tom čase riaditel'a Ernst múzea v Budapešti a častého návštevníka Levoče, sa začal zaujímat' o tvorbu Jozefa Czauczika, ktorého ako sám píše ,jehož dílo jsem vlastně objevil. "8 Začal publikovat' v košických novinách. Vyštudoval miestnu reálku, kde mal výborných profesorov, napríklad spisovatel'a Dezső Szabóa, ktorého zmieńuje aj vo svojom nekrológu a pod ktorého vplyvom sa dostal do revolučného varu v roku 1918. Vtedy vstúpil do komunistickej bunky mládeže, preto ho po páde Mad’arskej republiky rád uväznili, ale z väzenia z Ostrihomu sa mu podarilo ujst'. ${ }^{9}$ V roku 1921 bol naspät' na Slovensku. Ked’že $\mathrm{v}$ novom štáte ešte nefungovala univerzita, rozhodol sa íst' do Viedne, kde sa zapísal na Vysokú školu pre medzinárodný obchod, a čoraz viac sa zaujímal o výtvarné umenie. ${ }^{10}$ Počas viedenského štúdia bol

Osobný fond Vojtech Tilkovský (d’alej OF VT), inv. č. 12 A 1 - Prehl'ad odbornej činnosti. Tilkovský mu pomáhal pri súpise pamiatok na Spiši.

8 Ibidem. Fragment mal publikovat' v Prager Presse, 1924.

9 OF VT, inv. č. 12 A 4 - Nekrológ (vlastný), 24. 6. 1974.

${ }^{10} \mathrm{OF}$ VT, inv. č. $12 \mathrm{CH} 10$ - Fotografie - osobné; nový fond - Meldungsbuch der Hörers Hochschule für Welthandel in Wien, školský rok 1921/22, 1922/23. 


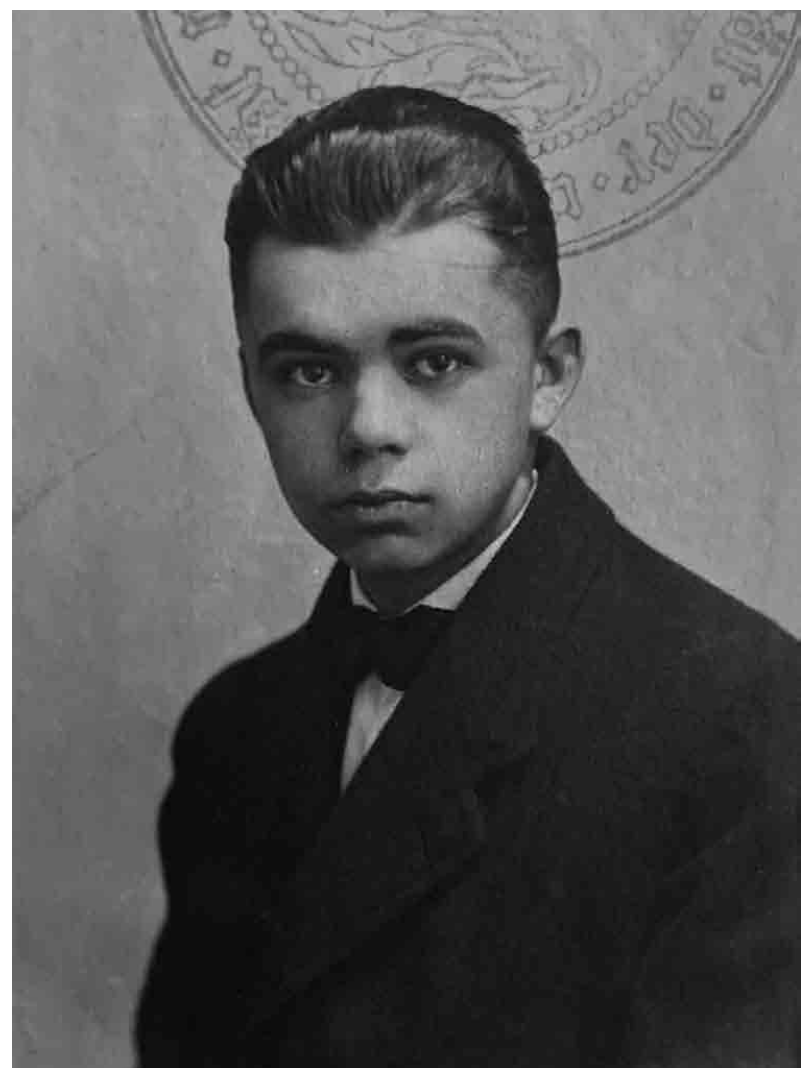

Obr. 2: Vojtech Tilkouský, 1922. Foto: Archiv SNG.

v kontakte s viacerými mad'arskými emigrantmi predovšetkým s Lajosom Kassakom. Venoval sa primárne medzinárodnému obchodu ale i štúdiu germanistiky a romanistiky a postupne sa vypracoval na jazykovo vel'mi zdatného poslucháča, aktívne ovládal francúzštinu, nemčinu, mad’arčinu mal ako materinský jazyk, pasívne pol’štinu, ruštinu a angličtinu. Ako mimoriadny poslucháč navštevoval prednášky prof. Maxa Dvořáka ${ }^{11}$ na Filozofickej fakulte viedenskej univerzity (obr. 2) ${ }^{12}$ a po jeho smrti v roku 1921 pokračoval u prof. Josepha Strzygowského.

${ }^{11}$ Uvádza to vo svojom nekrológu, na jeho hodiny chodil pravdepodobne súkromne, ako riadny študent je vedený ž od roku 1922. Vid'. pozn. 9.

${ }^{12}$ Viac k tejto téme pozri: BAKOŠ, J.: Štyri trasy metodológie dejín umenia, Bratislava 2000, s. 61-66.

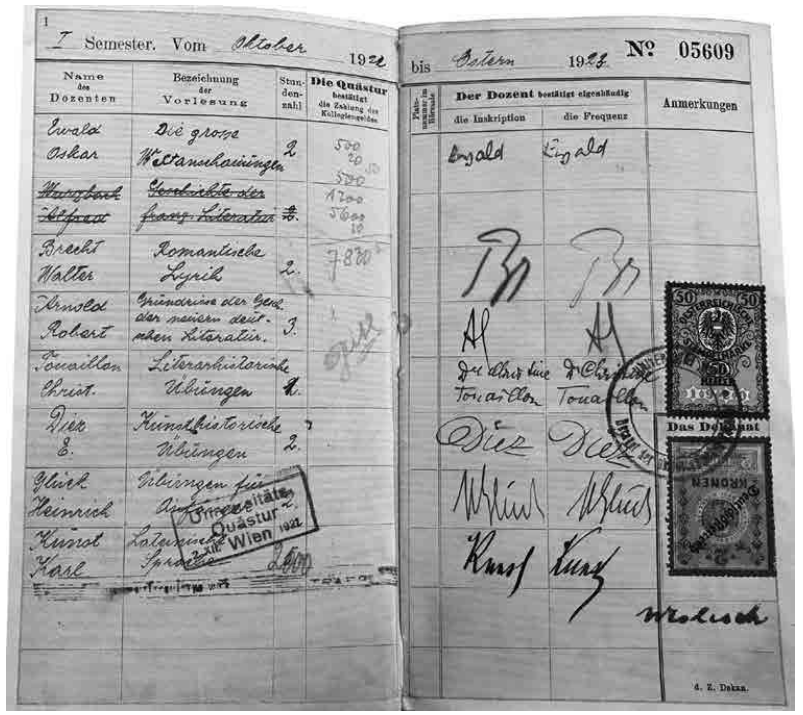

Obr. 3: Predmety na Filozofickej fajkulte Viedenskej univerzity, Index V. Tilkovskébo 1922/1923. Foto: Archiv výtvarnébo umenia SNG, Osobný fond $V$. Tilkouský, apendix.

Na Filozofickej fakulte vo Viedni študoval v rokoch 1922 - 1924, ako dokladajú zachované zápisy v indexe. ${ }^{13}$ Absolvoval hodiny u prof. Strzygowského z dejín umenia, u Oskara Ewalda predmet Vel'ké svetové výstavy a u Ernesta Dieza Umeleckohistorické cvičenia (obr. 3). Tieto prednášky si dopíňal hodinami z dejín literatúry a filozofie, francúzskeho a latinského jazyka. V roku 1922 podnikol cestu do Nemecka, kde mohol teoretické znalosti aplikovat' na výtvarný materiál.

Po založení seminára dejín umenia na Filozofickej fakulte UK sa Tilkovský v roku 1924 vrátil do Bratislavy a stal sa poslucháčom Františka Žákavca, ktorého vplyv si vel'mi cenil. Na štúdium získal finančnú podporu zo strany Ministerstva školstva a národnej osvety. František Žákavec pôsobil na UK v rokoch 1937 - 1924, kde bol zakladatel'om vôbec prvého seminára dejín umenia na Slovensku. ${ }^{14}$

${ }^{13}$ OF VT, nový doplnok. Meldungsbuch des ausserordentlichen Hörers. Philosophischen Fakultät der Universität zu Wien, 1922/23, 1923/24. Býval na Marxergasse č. 13.

${ }^{14}$ BAKOŠ, J.: Český dejepis umenia a Slovensko. In: Uméní, XXXIV, 1986, č. 3, s 212; MLYNÁRIK, J.: Ceskí profesori na Slovensku, 1. diel, Praha 1994, s. 152-153. 
„Ale jeho pedagogické pôsobenie v Bratislave nebolo ovel'a plodnejsie. Ked'v roku 1936 odchádza zo zdravotných dôvodov ako pät'desiatosemročný do dôchodku, zanecháva za sebou iba dvoch slovenských řiakov - Vojtecha Tilkovskébo a Aľ̌betu Güntherovú Mayerovú. "N5 Na krátko po ňom pôsobia archeológ Jan Eisner a ako externista študent Maxa Dvořáka Eugen Dostál z Brna. Z rovnakého obdobia, kedy študoval i Tilkovský, poznáme aj zápis predmetov od dr. Güntherovej a na predmetoch u prof. Žákavca a lektora Jána Hofmanna ${ }^{16}$ boli s Tilkovským spolužiaci. Podl'a zachovaného indexu z rokov 1924/25 navštevoval prednášky z dejín umenia, francúzskej a nemeckej literatúry, filozofie, archeológie (obr. 4). ${ }^{17}$ Dejiny európskeho umenia, dejiny starorímskeho umenia a seminár $\mathrm{k}$ dejinám umenia viedol v zimnom semestri profesor Žákavec a v letnom na to nadviazal dejinami 19. storočia, dejinami umenia antického a seminárom. Hofman ho vyučoval predmet Vývoj stavitel'stva miest od 19. storočia $\mathrm{v}$ pomere $\mathrm{k}$ ochrane pamiatok. $\mathrm{V}$ d'alšom školskom roku 1925/2618 absolvoval Tilkovský na-

${ }^{15}$ BAKOŠ, J.: Príbeh zakliatej vedeckej disciplíny / Seminár dejín umenia na bratislavskej univerzite. In: Pocta Václavovi Menclovi. Zbornik śtúdii k otázkam interpretácie stredoeurópskeho umenia. Eds.: BOŘUTOVÁ, D. - ORIŠKO, Š., Bratislava 2000, s. 10.

${ }^{16}$ Prišiel na Slovensko v roku 1919 a stal sa referentom novovzniknutého Vládneho komisariátu na ochranu pamiatok na Slovensku. Poznatky z praxe prednášal svojim študentom na UK. JANKOVIČ, V.: Dejiny pamiatkovej starostlivosti na Slovensku v rokoch 1850 - 1950. In: Monumentorum tutela, 1973.

17 Soznam prednášok, na ketoré bol zapisaný jako riadny posluchač, Československá štátna univerzita v Bratislave, školský rok 1924/1925, OF VT, appendix - Etika / Král; Dejiny novodobých teórií pedagogických / Chlup; Dejiny európskeho umenia, Dejiny starorímskeho umenia, Seminár dejín umenia / Žákavec; Moliére a komédia francúzska, seminár / Haškovec; Dejiny nemeckej literatúry, Herder, vybrané časti z nemeckej literatúry; Proseminár germánsky, seminár germánsky / Krejči; Dejiny novovekej filozofii, seminár filosofický / Tomsa; Psychologia / Chlup; Úvod do štúdia praehistorickej archeológie / Eisner; Výklad o slovenskom jazyku / lektor Haluziczky; Explication de textes: Victor Hugo, Euriadnus / lektor Chollet; La vie francaise / lektor Chollet; Logika, seminár filosofický / Kral; Hlavné smery v modernej filosofii / Tomsa; Dejiny nemeckej literatúry, Herder život a dielo; Proseminár germánsky, seminár germánsky / Krejči; Francúzsky verš, seminár / Haškovec; Dejiny umenia XIX.

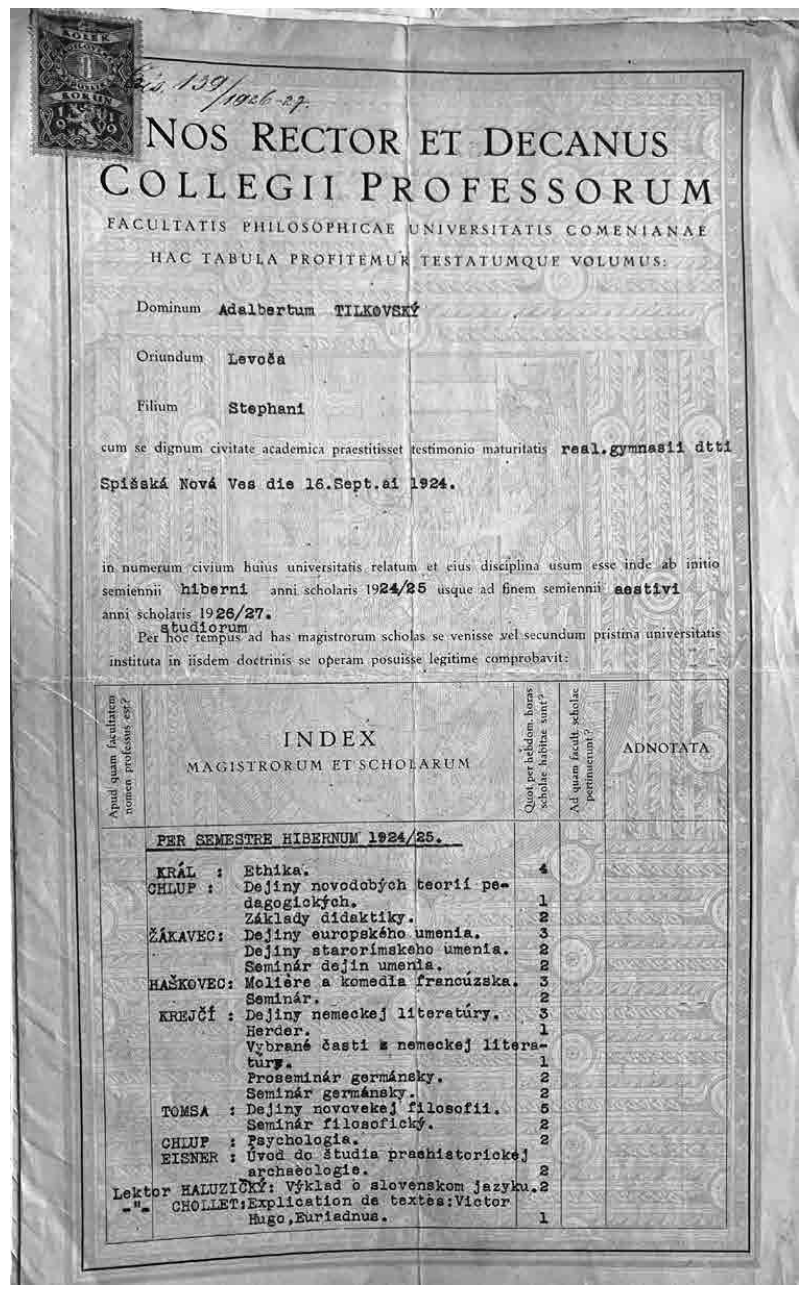

Obr. 4: Zoznam predmetov na UK v Bratislave, 1924/1925. Foto: Archiv výtvarnébo umenia SNG, Osobný fond $V$. Tilkovský, apendix.

Storočia; Dejiny umenia antického ; Seminár dejín umenia / Žákavec; Stredoškolská didaktika, Dejiny paedagogických teorií / Chlup; Hygiena / Ružička; Nové smery v čsl. Literatúre / Pražák; Kurs jazyka gréckeho / Kolař; Vývoj stavitel'stva miest od 19 stor. v pomere k ochrane pamiatok / lektor Hofmann; Výklad o slovenském jazyku / Haluziczky; Cour 2éme degré; Explication des textes / lektor Chollet.

${ }^{18}$ Ibidem, školský rok 1925/1926 - Logika; Seminár filosofický / Kral; Dejiny paedagogiky; Stredoškolská didaktika; Seminár paedagogický / Chlup; Hviezdoslav a jeho doma; Seminár / Pražak; Dejiny francúzskej literatúry / Haškovec; Hlavné zjavy nemeckej literatúry doby prítomnej; Goethe; Seminár / Krejči; Moderné umenie; Krešt’anská antika; Seminár / Žákavec; Cours 2éme degér / lektor Chollet; O spisoch a katastroch pamiatok / lektor Hofmann; a v letnom semestri: Logika; Seminár filosofický / Král; Dejiny paedagogicky; 
sledovné predmety so Žákavcom - Moderné umenie, krest'anská antika a seminár a v letnom semestri dejiny umenia 19. storočia, dejiny umenia stredoveku a povinný seminár. O spisoch a katastroch pamiatok prednášal ako lektor Hofmann. Z Tilkovského školských prác sa dozvedáme, že sa venoval i umeniu 19. storočia, kde využíval svoje znalosti mad'arského jazyka. V roku 1924 vypracoval seminárnu prácu - rozbor Divaldového textu Felvidéki sétat, ktorá vyšla len rok pred tým. ${ }^{19} \mathrm{~V}$ rámci seminára podnikol niekol'ko exkurzií do Čiech, Rakúska, Pol'ska a v roku 1925 vd'aka podpore svojho profesora absolvoval dvojmesačný študijný pobyt v Ríme a o rok neskôr v Krakove. Popri tom študoval aj francúzštinu a nemčinu. Žákavec rozhodol aj o Tilkovského celoživotnom záujem o tvorbu maliara Dominika Skutezkého, ktorého na jeho odporúčanie spracoval ako svoju diplomovú prácu.

Pri porovnaní publikačnej činnosti profesora Žákavca nachádzame paralely aj u Tilkovského. ${ }^{20}$ Žákavec sa venoval výskumu českého maliarstva, predovšetkým osobností ako Josef Mánes, Mikoláš Aleš, Ján Preisler alebo Max Švabinský. Spájal ich napríklad záujem o Josefa Mánesa, o ktorom neskôr vydal Tilkovský prácu v mad'arskom jazyku. K svojmu profesorovi mal vel'mi dobrý vzt'ah, čoho dôkazom je aj súbor výstrižkov článkov o Žákavcovi, ktoré Tilkovský opatroval. ${ }^{21} \mathrm{~V}$ roku $1971 \mathrm{mal}$ Tilkovský prednášku v pretóriu stredoslovenskej galérie v Banskej Bystrici. Bol tu vystavený aj dnes nezvestný obraz z maliarovho raného obdobia s mo-

Stredoškolská didaktika; Seminár paedagogický / Chlup; Ludstvo v dobe predhistorickej; Archeologické praktikum / Eisner; Literárna Levoča / Pražák; Dejiny francúzskej literatúry / Haškovec; Dejiny nemeckej literatúry; Goethe; Seminár / Krejč́; Dejiny umenia XIX. storočia; Dejiny umenia v stredoveku; Seminár pre dejiny umenia / Žákavec.

${ }^{19}$ DIVALD, K.: Felvidéki seták. Budapest 1925.

${ }^{20}$ OF VT, inv. č. 12 C 16 - písomnosti Žákavec. Zachované sú Tilkovského poznámky zo Žákavcových prednášok k umeniu 19. storočia.

${ }^{21}$ OF VT, inv. č. 12 C 14 - Príležitostné prednášky.

${ }^{22}$ Ibidem. tívom „Krajiny od Záhoria“. Ako spomína Tilkovský „Tu by som chcel poznamenat', že práve tento obraz upútal na pražskej výstave Jednoty výtvarných umelcov Slovenska roku 1922 pozornost' vynikejúceho ceského historika umenia profesora Františke a Źákavca, ktorý ma nabádal, aby som ako

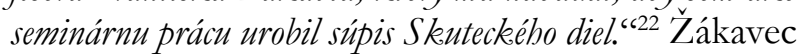
toto dielo vysoko hodnotil v Národních listech, ${ }^{23} \mathrm{kde}$ uverejnil kritiku z výstavy a zároveň nabádal mladú generáciu na spracovanie umelcovej pozostalosti. Našiel tu ako ukázal d’alší vývoj vhodného kandidáta v Tilkovskom.

V roku 1927 ukončil Tilkovský štúdium, prihlásil sa do školských služieb a prechodne pôsobil na štátnej reálke $\mathrm{v}$ Bratislave. ${ }^{24}$ Prispieval do Davu a priatelil sa s Vladimírom Clementisom a Ladislavom Novomestským. ${ }^{25}$ V roku 1927 sa stal redaktorom kultúrnej rubriky vtedy založeného vládneho časopisu, ktorý vychádzal v mad'arskom jazyku pod názvom $A$ reggel. Bol v kontakte s viacerými umelcami medzivojnového obdobia a to nielen v Československu, ale aj v Mad'arsku. Ako uvádza Ingrid Ciliusová: „V dvadsiatych rokoch 20. storočia na Slovenskupôsobili len dvaja školeni historici umenia: Gizela Weyde a Vladimir Wagner. Mladšiu generáciu činnú od tridsiatych rokov tvorili opät' len traja skoleni kunsthistorici: Alžbeta Mayerová, Jozef Cincike a Jaroslav Honza-Dubnicky. K najaktivnejšm komentátorom medzivojnového umenia patrili už spominani Jaroslav Honza-Dubnický, V ladimir Wagner, Vojtech Tilkovský, Jozef Cincike, či Pavol Fodor.“26 Už od školských rokov podnikol niekol'ko ciest, od Nemecka v 1922, Francúzska v 1924, Talianska

${ }^{23}$ Ž. [ŽÁKAVEC, F.]: Výtvarné umění. Domenik Skutezky (1848-1921). In: Národni listy, 11. 6. 1922, č. 157, s. 4

${ }^{24}$ LXXVII: Ročná zpráva Čs. štátnej reálky v Bratislave za školský rok 1926 1927. čast' 1. Učitel'ský sbor.

http://digit.spgk.sk/VYROCNE\%20SKOLSKE\%20 SPRAVY /VYR \%20SKOL $\% 20$ SPRAVY\%20SLOV $\% 20$ SKOL $/ \%$ C4\%8Ceskoslov. $\% 20 \%$ C5 $\%$ A 1 t $\%$ C3\%A1t. $\% 20$ re $\%$ C3\%A $1 \mathrm{lka} \% 20 \mathrm{v} \% 20$ Bratislave/77. $\% 20$ r. $\% 20$ zpr. $\% 20$ \%C4\%8Dsl.\%20\%C5\%A1t $\%$ C3\%A 1 t. $\% 20$ re $\%$ C3\%A $11-$ ky\%20v\%20Bratislave.\%201926-1927.pdf (20.1.2020).

25 TILKOVSZKÝ, B.: Svetová kríza umenia. In: DAV, 1925; č. 2, s. 36-38. Tragédia Maxa Lindera, In: $D A V, 2,1926$, č. 3; Výstava Gustáva Böhma. In: Slovenský dennike, 13. 5. 1926.

${ }^{26}$ CIULISOVÁ, I.: Dejepis umenia na Slovensku. Vybrané kapitoly. Bratislava 2011, s. 16, 23, 37. 


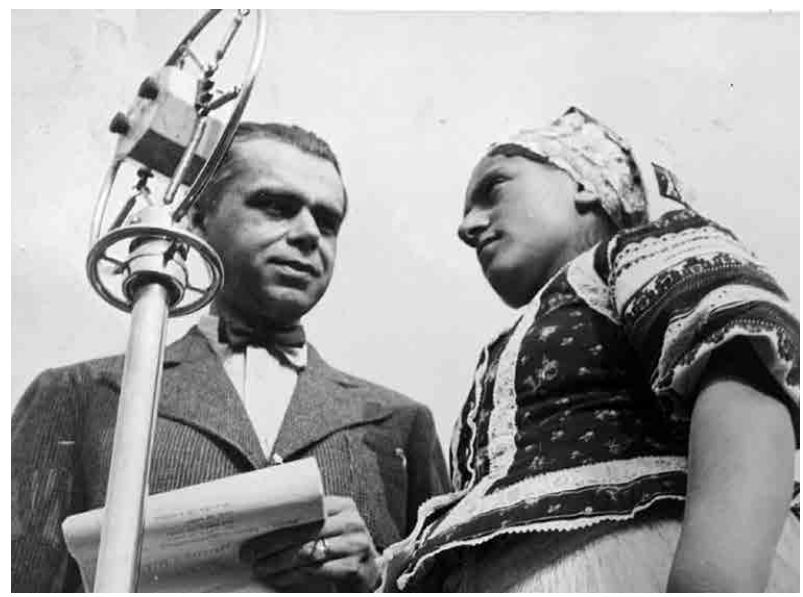

Obr. 5: Vojtech Tilkovský pri nabrávaní rozhlasovej relácie, Žirany 1938. Foto: Archiv RTVS.

a severnej Afriky o rok na to v roku 1926 do Pol'ska. Ako štipendista absolvoval v rokoch 1928 - 29 cestu do Paríža, kde sa dostal do centra výtvarného umenia tohto obdobia. Navštevoval prednášky profesorov René Schneidera a Henri Focillona na Sorbonne. Skúmal tvorbu umelcov ako Brancusi, Picasso, Dalí. Ďalšie cesty podnikol v roku 1930 do Švajčiarska, v roku 1936 do Juhoslávie, Albánska, Grécka a v roku 1938 do Lotyšska, Estónska a Fínska. V roku 1928 sa stal členom Sdruženia mad’arských novinárov v Československu za periodikum $A$ reggel, kde bol vedený do roku 1936. Po návrate z Paríža v roku 1929 sa prest'ahoval do Prahy, kde pôsobil ako novinár ${ }^{27}$ a podnikal. V roku 1931 sa oženil s Máriou Jelenekovou, ktorá vyštudovala Filozofickú fakultu v Prahe a Bratislave a pôsobila ako odborná pracovníčka vo Výskumnom ústave odborného školstva $\mathrm{v}$ Prahe.

Tilkovský sa snažil podnikat', k čomu využil i vo Viedni získané znalosti zo štúdia medzinárodného

\footnotetext{
${ }^{27}$ Pre výtvarné umenie treba zmienit' napríklad jeho text TILKOVSKÝ, V.: Formové problémy maliarstva. In: Slovenské dielo, 1, 1929, č. 3, s. 133-140.

${ }^{28}$ List V. Tilkovského na V. Wagnera, 13. 12. 1930 - Literárny archív (d’alej LA), Slovenská národná knižnica Martin (d’alej SNK), inv. č. 157 A 35.

${ }^{29}$ List V. Tilkovského na V. Wagnera, 26.3.1931 - LA SNK, inv. č. 157 A 35.
}

obchodu. V roku 1929 založil nakladatel'skú spoločnost' Litevna - Nakladatelství naučných spisů oddechové četby v Praze, ktorá mala vo svojom portfóliu vydávanie kníh a grafických a fotografických albumov na rôzne témy (napríklad zborník Slovensko Masarykovi). Kvôli tomuto svojmu podnikaniu sa stal členom Zvazu knihkupcov a nakladatel'ov československej republiky v Prahe. Firma pôsobila do roku 1932 a o dva roky na to sa Tilkovský vzdal koncesie, čo bolo zapríčinené dosahom hospodárskej krízy. Vd’aka Litevne sa Tilkovský dostal pravdepodobne po prvýkrát do kontaktu aj s historikom umenia Vladimírom Wagnerom. Dokladá to ich zachovaná korešpondencia, ktorá $\mathrm{v}$ priebehu ich spolupráce prešla od formálne do vel'mi familiárneho vzt'ahu. V decembri 1930 Tilkovský požiadal práve Wagnera, aby vytvoril heslá $\mathrm{k}$ výtvarnému umeniu na Slovensku do pripravovaného Slovenského literárneho almanachu. ${ }^{28} \mathrm{~V}$ marci $1931 \mathrm{mu}$ už píše - „Drabý Vladko, môj jediný... kludne si sadneš do fotelu, aby si, na základe Tvojej kniby a Tvojich vedomosti, konečne napisal nám dejiny výtvarnébo umenia na Slovensku, dla mo:̌nosti súpis pamiatok západnébo Slovenska. "29 Tilkovský vydal Slovenský literárny almanach v roku 1931 a o dva roky na to Slovenský naucný slovnike. Na túto jeho činnost' spomína aj jeho kolega Július Kálman „Bolo to na svoju dobu priekopnicke, náukovo-typograficky-organizačne náročné dielo, ktoré doteraz slúži ako zdroj informácii. "30 V rokoch 1933 až 1945 pracoval Tilkovský v Československom rozhlase ako redaktor pre programy v mad'arskom jazyku a od roku 1939 pre literárne a vzdelávacie oddelenie a od $1940 \mathrm{v}$ zahraničnej redakcii (obr. $5,6) \cdot{ }^{31} \mathrm{~V}$ novinách a časopisoch medzivojnového obdobia sa jeho meno v kontexte rozhlasovej činnosti spomína vel'mi často. Popri tom neustále sledoval umeleckú scénu, písal prednášky, články a štúdie. $\mathrm{Na}$ Univerzite Komenského navštevoval prednášky profesora Eugena Dostála ${ }^{32}$ a v roku 1939 zložil

${ }^{30}$ KÁLMAN 1978, c. d. (v pozn. 4), s. 4.

${ }^{31} \mathrm{~K}$ činnosti v rozhlase pozri Archív Slovenského rozhlasu, osobný fond Tilkovský.

32 Slovnik historikù umèni, výtvarných kritikü, teoretiku a publicistu $v$ českých zemich a jejich spolupracovniki z pribuzných obori (asi 1800 - 2008), 1. sz. Ed. SLAVÍČEK, L. Praha 2016, s. $241-242$. 
rigoróznu skúšku. Jeho práca bola zameraná opät' na Skutezkého. ${ }^{33}$

V čase druhej svetovej vojny sa Tilkovský venoval primárne práci pre rozhlas a bol vedúcim zahraničného oddelenia. V rámci inštitúcie mal podporu svojich vedúcich čo dokladá aj agenda smerom $\mathrm{k}$ úradu propagandy, ked’že bolo známe jeho lavicové zmýšl'anie. Zo 7. 1. 1942 sa zachoval doklad: Žiadost' Slovenského rozhlasu, aby Úrad propagandy ponechal V. Tilkovského v službách rozhlasu. ${ }^{34} \mathrm{O}$ rok neskôr bola vypracovaná aj Tilkovského kádrová charakteristika. ${ }^{35} \mathrm{~V}$ roku 1942 sa snažil zorganizovat' výstavu slovenského umenia v Ríme a písal napríklad i o benátskom bienále, ktoré bolo silne ovplyvnené nacistickou propagandou. ${ }^{36} \mathrm{~V}$ rokoch $1942-43$ viedol v Ústave talianskej kultúry v Bratislave kurz talianskeho umenia. I ked' jeho pracovná činnost' počas druhej svetovej vojny súvisela s prácou redaktora, nad'alej sa venoval aj výtvarnému umeniu, písal kritiky, štúdie. Bol členom Spolku slovenských výtvarných umelcov a v roku 1943 sa mu podarilo vydat' pre Osvetové ústredie pri Ministerstve školstva a národnej osvety v rámci edície „Umelecké dielo“ knihu pod názvom Výtvarná pozostalost' Milana Th. Mitrovského. V Slovenskom múzeu sa konala i výstava tohto maliara, ktorú otvoril vtedajší šéf Úradu propagandy Tido J. Gašpar. ${ }^{37}$

Podl'a spomienok Karola Vaculíka sa v roku 1943 uvažovalo o vydávaní časopisu Slovenské umenie, ktoré malo byt' venované slovenskej kultúre a umeniu. Časopis mal byt' redigovaný práve Tilkovským a Wagner pozýval Vaculíka, aby s nimi spolupracoval, „ostalo asi len pri zámere. ${ }^{\text {"38 }}$ Vydavatel'om mal byt' Čas,

${ }^{33}$ OF VT appendix, bez inventára.

${ }^{34}$ Inventáre a katalógy fondov a zbierok archívu Ústavu marxizmu-leninizmu, ÚV KSS v Bratislave, - IX. Úrad propagandy Slovenskej republiky, s. 73, č. 628, Žiadost' Slovenského rozhlasu, aby ÚP ponechal V. Tilkovského v službách rozhlasu. 7. 1. 1942. http://www.vhu.sk/data/files/586.pdf (20.1.2020).

${ }^{35}$ Ibidem, s. 96, č. 848 - Kádrová charakteristika dr. Vojtecha Tilkovského, pracovníka Slovenského rozhlasu, 1943.

${ }^{36}$ OF VT, inv. č. 12 A 36 - Korešpondencia, Úrad propagandy v Bratislave, 23. 11. 1942; 12 A 41 - Korešpondencia, Vyslanectvo Slov. rep. v Ríme, 28. 10. 1942. Pozri : Die slowakische

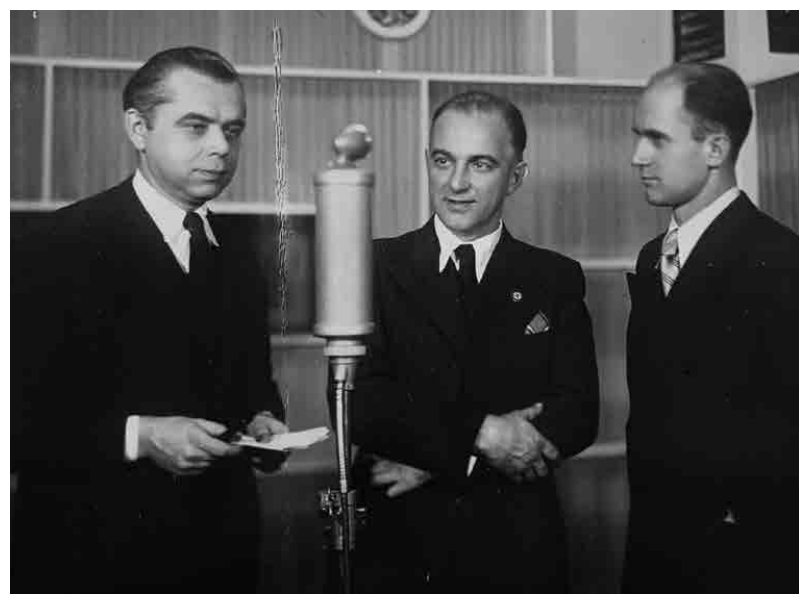

Obr. 6: Vojtech Tilkovský pravdepobne so Zúbekom a Randýskom, Ceskoslovenský rozhlas, okolo 1938. Foto: Archiv RTVS.

nakladatel'ská účastinná spoločnost' a kníhkupectvo v Bratislave, ktoré sídlilo na Gunduličovej ulici č. 1/a. Pre Josefa Cincíka sa podujal Tilkovský napísat' prácu o gotickom sochárstve. ${ }^{39} \mathrm{~V}$ roku 1944 sa martinská tlačiareň Neografia rozhoduje o podpore vydávania časopisu týždenníka Vesna, ktorý má byt' zameraný na správy z umenia a kultúry. Zámerom bolo i vydávanie monografií o starom i súčasnom umení. Nakladatel'sky ho mal zabezpečovat' pán V. H. Kurtha, za odbornej spolupráce práve Tilkovského, Mariána Várossa a Vaculíka. V roku 1944 vydal Tilkovský v rámci edície Súčasné slovenské umenie Spolku slovenských výtvarných umelcov publikácia o Mudrochovi. ${ }^{40}$ Bol v kontakte i s Jánom Smrekom,

Bildende Kunst auf der Biennale. In: Slowakische Rundschau, III, 1942, 22.

${ }^{37}$ OF VT, inv. č. 12 H 2 - Pozvánky. Z otvorenia je i zvukový záznam - Archív RTVS, Reportáž z otvorenia výstavy Milana Thomku Mitrovského, ev. č. ID 9117201001.

38 PETERAJOVÁ, L: Nepýtaj sa na svoj osud... Život a dielo Karola Vaculikea. Bratislava 2005, s. 64.

${ }^{39}$ OF VT, inv. č. 12 A 49 - Korešpondencia, Jozef Cincík, 1941, 42.

40 TILKOVSKÝ, V.: Mudroch. Bratislava 1944. Na knihe spolupracoval is Alžbetou Güntherovou-Mayerovou. 
pre ktorého občas písal články o súčasnom výtvarnom umení. ${ }^{41}$

Po skončení druhej svetovej vojny sa prest'ahoval do Prahy, kde bol menovaný odborným radcom na ministerstve priemyslu a mal na starosti umelecký priemysel a vytvorenie novej organizačnej štruktúry. Funkciu výtvarného referenta ministerstva zastával do roku 1951. Po reorganizácii ministerstva bol prevedený do pôsobnosti Ministerstva lesov a drevárskeho priemyslu do tzv. Skupiny tvarového vývoja Výskumného ústavu technológie drevopriemyslu, od roku 1945 bol vedúcim tohto oddelenia. ${ }^{42}$ V roku 1948 dostal potvrdenie od preverovacej komisie Československého rozhlasu, ktoré reaguje na námietky voči nemu vznesené. Medzitým ale svoje miesto v rozhlase opustil.

Od roku 1948 sa aktívne podiel'al na organizácii výtvarného života na Slovensku, bol funkcionárom Ústredného zväzu československých výtvarných umelcov a bol členom viacerých komisií ${ }^{43}$ a porôt, plagátovej komisie ministerstva kultúry, Zväzu československých umelcov, slovenská sekcia. ${ }^{44}$ Získal ponuku pre vydavatel'stvo Sfinx na vypracovanie štúdii o slovenskom gotickom umení a umení rokov 1848/1948, čo plánoval už počas Slovenského štátu. ${ }^{45}$ Okrem toho v roku 1948 vstúpil aj do Komunistickej strany Československa. V tomto kontexte je zaujímavý list, ktorý mu adresoval výbor Komunistickej strany v roku 1953. Ako prísne dôverné žiada Tilkovského, aby sa vyjadril či umelci ako Benka, Mallý a Fulla sa stali súčast'ou skupiny intelektuálov, ktorí boli na strane Slánskeho, ,nakollko sa na Slovensku prejavil uplyv slánskovśtiny vo výtvarnej oblasti a ktorí súdrubovia boli nositelmi odbalených úcbyliek." Tilkovský na to vel'mi diplomaticky

${ }^{41}$ List V. Tilkovského na J. Smreka, 9. 9.1942, článok o súčasnej nemeckej plastike, LA SNK, inv. č. 181 S 26. Pozri i SMREK, J.: Poézia moja láska, II. diel. Martin 1989, s. 74.

${ }^{42}$ List 16. záŕí 1946; List z 21. dubna 1950, OF VT, inv. č. 12 A 5, Korešpondencia, Čsl. Společnost, 1946, 1950. Pozri aj OF VT, inv. č. 12 A 1 - Životopis z roku 1956.

${ }^{43}$ OF VT, inv. č. 12 A 2 - Korešpondencia, Archeologická spoločnost' pri ČAV, 19. 2. 1947.

${ }^{44}$ OF VT, inv. č. 12 A 31 - Korešpondencia, Svaz přátel SSSR v Československu, 15. 3. 1946. odpovedá „moja odpoved' nemồže byt' meritórna, ked’že nepoznám uznesenie výročnej členskej schôdzky ZO KSS pri SCSLU a tak neviem, o co vlastne ide. " $46 \mathrm{~V}$ tomto kontexte treba zdôraznit' Tilkovského dobré vzt'ahy s výtvarníkmi na Slovensku. Dokladá to napríklad zachovaná korešpondencia $\mathrm{z}$ medzivojnového, ako aj povojnového obdobia (Alexy, Angyal, Bazovský, Galanda, ${ }^{47}$ Gwerk, Reichentál, Weiner-Král' a d’alšî).

\section{Tilkovský a Slovenská národná galéria}

Ďalšia dôležitá udalost' pre slovenskú povojnovú kultúru súvisela so založením Slovenskej národnej galérie v roku 1948. Vladimír Wagner, ktorý Tilkovského oslovoval Beckó, ho oboznamuje so situáciou ohladne založenia národnej galérie. Informuje ho, že v kuratóriu je Ján Mudroch, Josef Kostka, Jaroslav Dubnický, Milan Škorupa, M. Jurkovič a on sám. Povereníctvo si želá, aby sa riaditel’om stal Karel Šourek, čo je podl'a neho Mudrochova aktivita. Ked’že sa dlho neozýval navrhol Wagner, aby sa riaditel'om stal Tilkovský, čo narazilo na odpor. Povereníctvo sa stále držalo svojho pôvodného nominanta ako uvádza aj Wagner. „Beckó pišem tak ako sa veci majú. Ale myslím, že ked' sa galéria institunje bude možné, aby si sa do nej dostalpredbežne ako kustos. Verim, že Šurek tu dlho nebude a potom azda by sa podarilo presadit, aby si prevzal vedenie. Ved' galéria, to je eśte dlhá história. Program, aký sme si sdr. Güntherovou vypracovali je dlhodobý a predpokladá dostatok výstavných miestnosti. ${ }^{648}$ I Josef Vydra v liste z roku 1949 píše „Myslim, že v Bratislavě tu galeri bez Vás nerozreši, a marné si stavi Mudroch proti Vám blavu. Jinak tam není nic nového. “49 Neskôr Wagner konštatuje, že i ked' má galériu rád, vel’mi sa do jej chodu začínajú starat' Mudroch a Vojtech Mensatoris,

${ }^{45}$ OF VT, inv. č. 12 A 26 - Korešpondencia, Sfinx, 1948.

${ }^{46}$ OF VT, inv. č. 12 A 45 - Korešpondencia, ZO KSS pri Zväze čsl. výtv. umelcov, 1953.

${ }^{47}$ OF VT, inv. č. 12 A 54 - Korešpondencia, Mikuláš Galanda, 29. 3. 1931.

48 OF VT, inv. č. 12 A 82 - Korešpondencia, Vladimír Wagner, 1949.

${ }^{49}$ OF VT, inv. č. 12 A 83 - Korešpondencia, Jozef Vydra, 1949. 
čo mu nevyhovuje. ${ }^{50}$ Vedenia SNG sa po jej založení ujal na krátku dobu Šourek a následne Vaculík.

V roku 1951 bol Tilkovský členom komisie, kuratória Slovenskej národnej galérie. Členovia komisie podnikli cesty po Slovensku, kde sa snažili získat' výtvarné diela do zbierok. Tilkovský bol kritizovaný, že sa venoval len odporúčaniam, ktoré mal od kolegov, hlavne od dr. Güntherovej Mayerovej. ${ }^{51}$ Predmetom jeho výskumu bolo predovšetkým umenie 19. storočia, ktorému mala byt' venovaná jedna z prvých väčších výstav v novej SNG. Tilkovský sa stal členom i pomerne rozsiahlej komisie k pripravovanej výstave, ktorá sa konala pod názvom Umenie 19. storočia. Realistický odkaz našej výtvarnej minulosti. V porote boli za teoretikov umenia Dubnický, Fodor, Güntherová, Kálmán, Mensatoris, Vaculík, Wagner. Na výstave spolupracovali i študenti dejín umenia Cidlinská, Petrová a Vámošiová, ktoré sa krátko po štúdiu venovali takisto výskumu umeniu 19. storočia. ${ }^{52}$

Pre Tilkovského bolo pomerne náročné získat' po roku 1948 pevné pracovné zaradenie na Slovensku. Komplikovala to aj jeho rodinná situácia, ked’že manželka a deti žili trvalo v Prahe (obr. 7). Omnoho ale náročnejšie bolo sa presadit' v 50. rokoch na pôde slovenského školstva a novovznikajúcich galérií. Ako už bolo doteraz zrejmé pokúšal sa uplatnit' napríklad v Slovenskej národnej galérii. Isté, pravdepodobne osobné animozity, jeho postavenie počas Slovenského štátu a následne po roku 1948 komplikovali. Preto sa nad'alej venoval výtvarnej publicistike a pôsobil ako redaktor vo vydavatel'stve Tvar, kde zredigoval 19 knižných publikácií z dejín výtvarného umenia. $\mathrm{V}$ jednom $\mathrm{z}$ listov s dr. Wagnerom, kedy mal Tilkovský na starosti vydanie monografie o Gustavovi Mallom vo vydavatel'stve Tvar, sa Wagner vyjadruje k SNG - „Od 1. septembra 1950 pracujem v Slovenskom muzeu, kde mi prípisy adresuj. Vypadol som aj z kuratória Galérie, neviem co sa tam robi, iba zpočutia, je to chaos." ${ }^{\text {c53 }}$ Wagner mal kvôli chorobe a úmrtí svojej manželky problém vyhotovit' knihu načas, k čomu bol Til-

\footnotetext{
${ }^{50}$ Ibidem.

51 PETERAJOVÁ 2005, c. d. (v pozn. 38), s. 110. Pozri bližšie: 60. rokov otvorené, Ročenka SNG. Eds. KUSÁ, A. - LUDIKOVÁ, Z. Bratislava 2008, s. 30-31.

${ }^{52}$ Ibidem, s. 112.
}

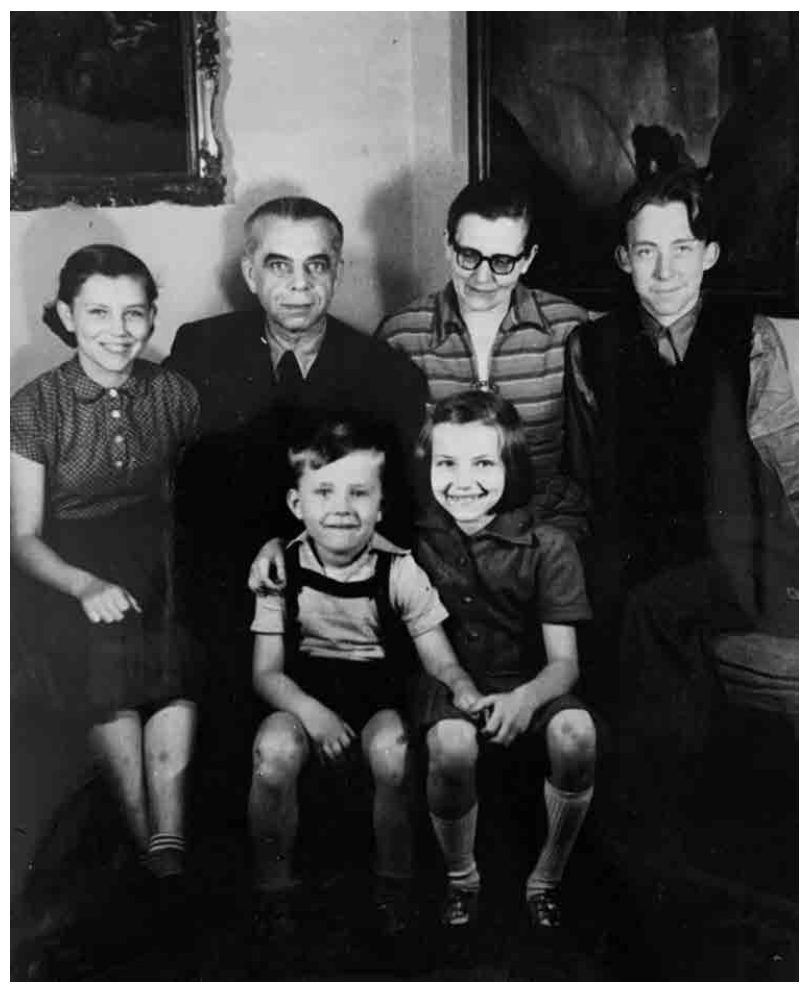

Obr. 7: Vojtech Tilkovský s rodinou. Foto: Archiv výtvarnébo umenia SNG, Osobný fond V. Tilkouský, apendix.

kovský vel'mi empatický. Kniha nakoniec vyšla až v roku 1953. V rovnakom čase pracoval Tilkovský i na Červenom Kameni, o čom píše v liste Wagnerovi a zároveň sa snažil aktivizovat' i na výtvarnej scéne, kedy sa podiel'al na príprave zjazdu československých výtvarníkov. ${ }^{54} \mathrm{~V}$ roku 1956 sa Tilkovský snažil uplatnit' v Kabinete pre teóriu a dejiny umenia pri Československej akadémii vied, čo neprešlo. Zachovala sa jeho žiadost' a životopis, kde jedným z hlavných argumentov jeho záujmu je potreba sa venovat' čisto dejinám umenia a vede. V rovnakom roku na základe odporúčania akademického maliara Štefana

53 List V. Wagnera na Tilkovského, 8. 1. 1951, korešpondencia, LA SNK, inv. č. 157 C 19.

${ }^{54}$ Oznamuje Wagnerovi aby si pripravil prednášku na zjazd na tému rozbor vývinu umenia od Bohúňa po Kerna. - List V. Tilkovského na V. Wagnera, 14. 8. 1951, LA SNK, inv. č. 157 A 35 . 
Bednára bol prijatý ako výtvarný redaktor Výtvarnébo života, kde pôsobil do roku $1959 .{ }^{55}$

\section{Tilkovský ako pedagóg}

Prvé pedagogické skúsenosti mal Tilkovský už počas druhej svetovej vojny, kedy viedol kurz dejín talianskeho umenia na Ústave talianskej kultúry v Bratislave. V rokoch 1948/1947 prednášal na Vysokej škole umelecko-priemyselnej v Prahe, kde mal prednášky $\mathrm{k}$ dejinám keramiky a za svoje pôsobenie dostal aj pod'akovanie zo strany vedenia školy. ${ }^{56}$ Z roku 1947 sa zachoval list z dekanátu odboru inžinierskeho stavitel'stva Slovenskej vysokej školy technickej v Bratislave, kde mu oznamujú, že ho nemôžu z finančných dôvodov ustanovit' za honorovaného docenta pre školský rok 1948/1947 a preplácat' mu cestovanie z Prahy do Bratislavy. „Co sa týka Vášbo uvolnenia k prednáškam na SVŠT oznamujem, že prezídium Min. priemyslu svojim pripisom z 22.V.1947 cóslo P 1/1-191/8/47 sa dotázalo na Poverenictvo školstva a osvety, či t.č. neni skutočne iný slovenský odborník pre ,dejiny umenia ${ }^{\text {“ }}{ }^{57}$ Ked’že sa táto vec stále nat'ahovala, Tilkovský nakoniec nenastúpil na letný semester a škola si našla náhradu. Sám dekan ho ale uist'oval, že z ich strany pretrváva záujem o jeho pedagogické pôsobenie. V liste architekta Emila Belluša z 20. januára 1948 sa dozvedáme, že škola bola vel'mi rozčarovaná byrokraciou Povereníctva a prosí Tilkovského, aby do budúcnosti zvážil svoju spolupráci s nimi. „Milýpán doktor! My budúci profesori na oddeleni architektury by sme vel'mi neradi, aby disciplina dejin umenia nebola bned'od začiatku riadne obsadená, preto prosil by som V ás ešte o veci znovu uvažovat' a vyjst' škole, snád' aj za určitých obetív ústrety. " ${ }^{58}$

V priebehu 50. rokov sa Vojtech Tilkovský dostal do kontaktu ako pedagóg predovšetkým s Filozofickou fakultou Slovenskej (od 1954 opät' Komen-

55 OF VT, inv. č. 12 A 40 - Korešpondencia, Ústredný zväz výtv. umelcov čsl., 1956, 58.

${ }^{56}$ OF VT, inv. č. 12 A 25 - Korešpondencia, Pokrok, 1946, 47. V roku 1950 sa stal členom poradného výboru. OF VT, inv. č. 12 A 42 - Korešpondencia, Vysoká škola umělecko-průmyslová v Praze, 1948, 50.

${ }^{57}$ OF VT, inv. č. 12 A 8 - Korešpondencia, Dekanát odboru inžinierskeho stavitel'stva SVŠT v Bratislave, 1947-48.

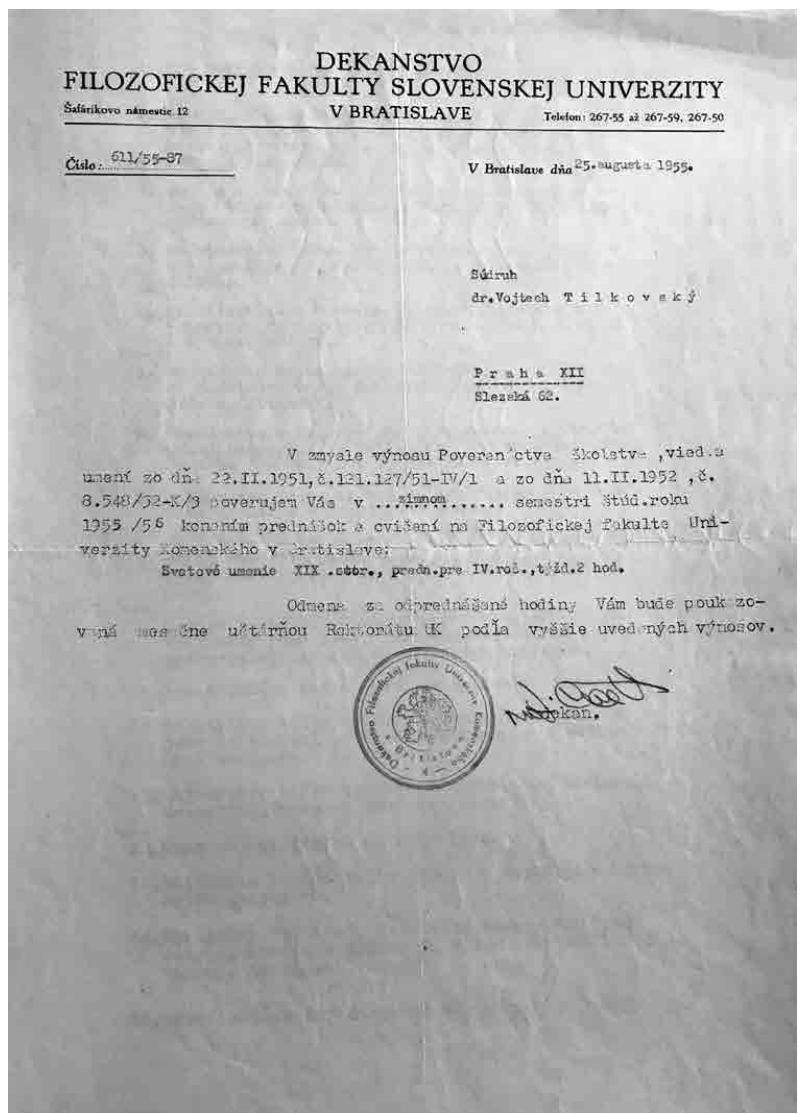

Obr. 8: List z. Dekanátu Filozofickej fakulty Slovenskej univerzity $v$ Bratislave, 23. augusta 1955. Foto: Archiv výtvarnébo umenia SNG, Osobný fond V. Tilkouský, 12 A9.

ského) univerzity. Nikdy nebol vedený ako interný pedagóg katedry, pracoval ako externista a mal na starosti predmety týkajúce sa primárne obdobia 19. storočia. Vo svojom životopise uvádza prvé hodiny do školského roka 1954/55. V učebnom pláne pre tento školský rok je uvedený ako pedagóg pre predmet „Světové umění 19. stoleti““.59 Zachoval sa

${ }^{58}$ OF VT, inv. č. 12 A 34 - Korešpondencia, SVŠT, 20. 1. 1948.

59 95+ Dejiny umenia na Univerzite Komenského v Bratislave. Eds.: KOLBIARZ CHMELINOVÁ, K. - BEŇOVÁ, K. Bratislava 2018, s. 98-99. Viac k situácii v školstve v priebehu 50. rokov pozri: KOLBIARZ CHMELINOVÁ, K.: University art history in Slovakia after WWII and its sovietizazion in the 50s. In: Artium Quaestiones, 30, Vroclav, 2019, s. 176, repr. 6. 


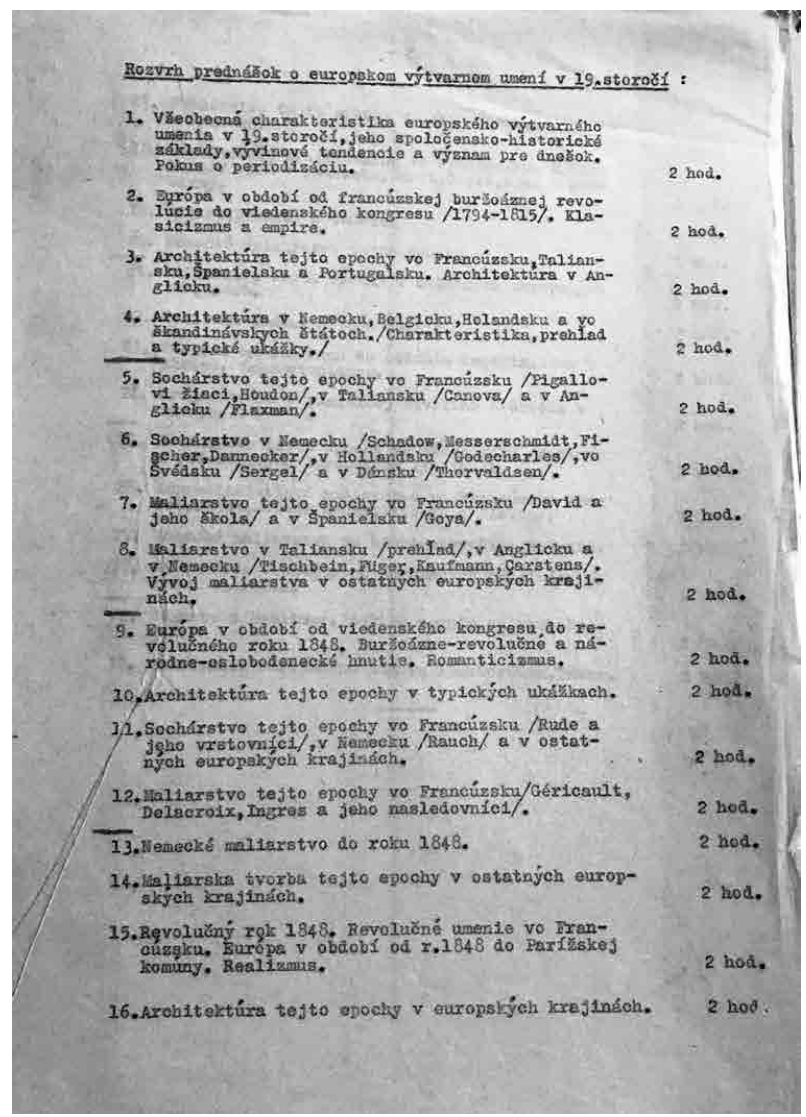

Obr. 9: Zoznam predmetov ke dejinám umenia 19. storočia. Foto: Archiv výtvarnébo umenia SNG, Osobný fond $V$. Tilkovský, 12 A 9.

list $\mathrm{z}$ dekanátu ${ }^{60}$ fakulty, kde sa nastavuje $\mathrm{v}$ zmysle výnosu z Povereníctva školstva, vied a umení vykonávat' prednášky 2 hodiny do týždňa $\mathrm{v}$ zimnom semestri v školskom roku 1955/56. (obr. 8) V tomto období pôsobili v odbore dejín výtvarného umenia v rámci Katedry vied o umení, na ktorej čele stál prof. Mikuláš Bakoš nasledovné osobnosti - Elena Dubnická, Alžbeta Güntherová-Mayerová, Rastislav Matuštík, Tomáš Strauss a Karol Kahoun. ${ }^{61}$ Ked' sa pozrieme na plán učebného procesu pre školský rok 1955 - 1956, tak renesanciu mal na starosti Kostka,

${ }^{60}$ OF VT, inv. č. 12 A 9 - Korešpondencia, Dekanstvo Filozofickej fak. Slov. univerzity v Bratislave, 25. 8. 1955.

${ }^{61}$ KOLBIARZ CHMELINOVÁ, K. - DAŇKOVÁ, L a kol.: Dejiny umenia na Filozofickej fakulte Univerzity Komenské-

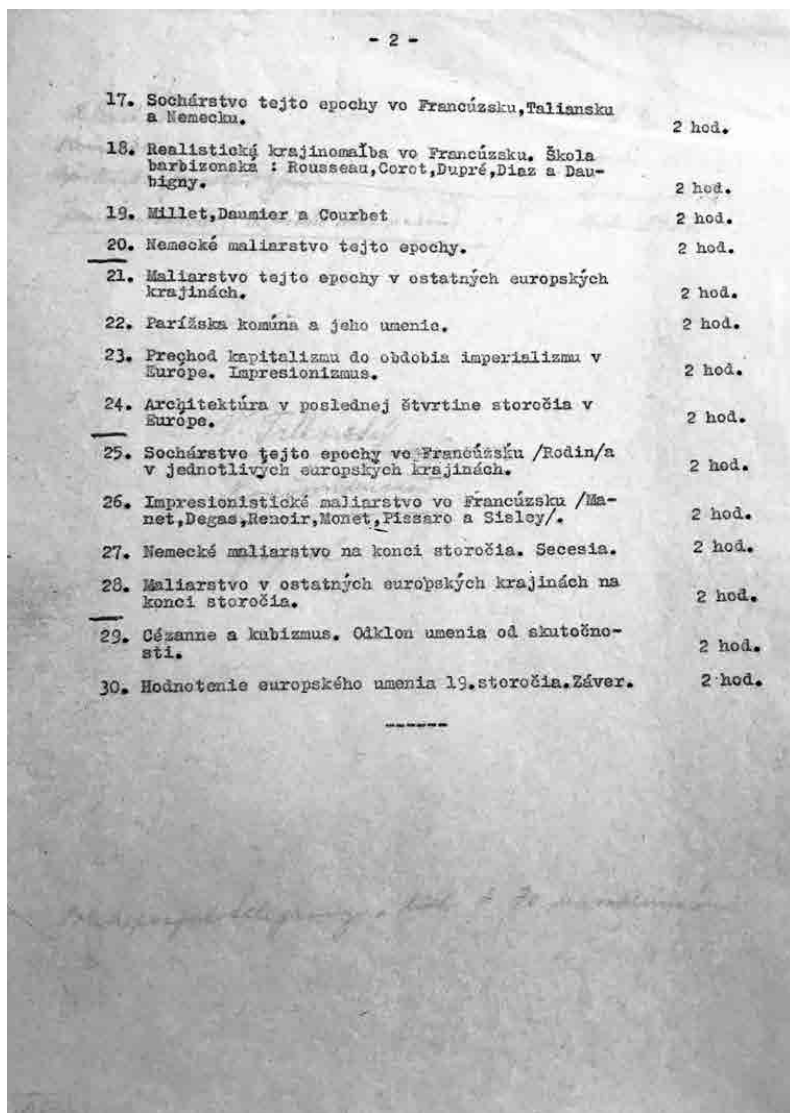

Obr. 10: Zoznam predmetov ke dejinám umenia 19. storočia. Foto: Archiv výtvarnébo umenia SNG, Osobný fond V. Tilkovský, 12 A9.

umenie 17. a 18. storočia Güntherová, ktorá učila aj umelecké remeslo a práve svetové umenie 19. storočia pripadlo Tilkovskému (obr. 9-10). Ruské umenie 18. a 19. storočia učil Váross a o české umenie toho istého obdobia sa delil s Matuštíkom. Tilkovský prednášal Svetové umenie XIX. storočia, pre 4. ročník a pripravil 30 prednášok v rozsahu 2 hod. ${ }^{62}$ Čo z toho sa naozaj realizovalo nie je známe. Rozsah bol od všeobecnej charakteristiky sledovaného obdobia a venoval sa postupne jednotlivým slohom s odkazom na architektúru, maliarstvo a sochárstvo.

ho v Bratislave. In: KOLBIARZ CHMELINOVÁ - BEŇOVÁ 2018, c. d. (v pozn. 59), s. 66.

${ }^{62}$ OF VT, inv. č. 12 G 5, prednášky na UK. 


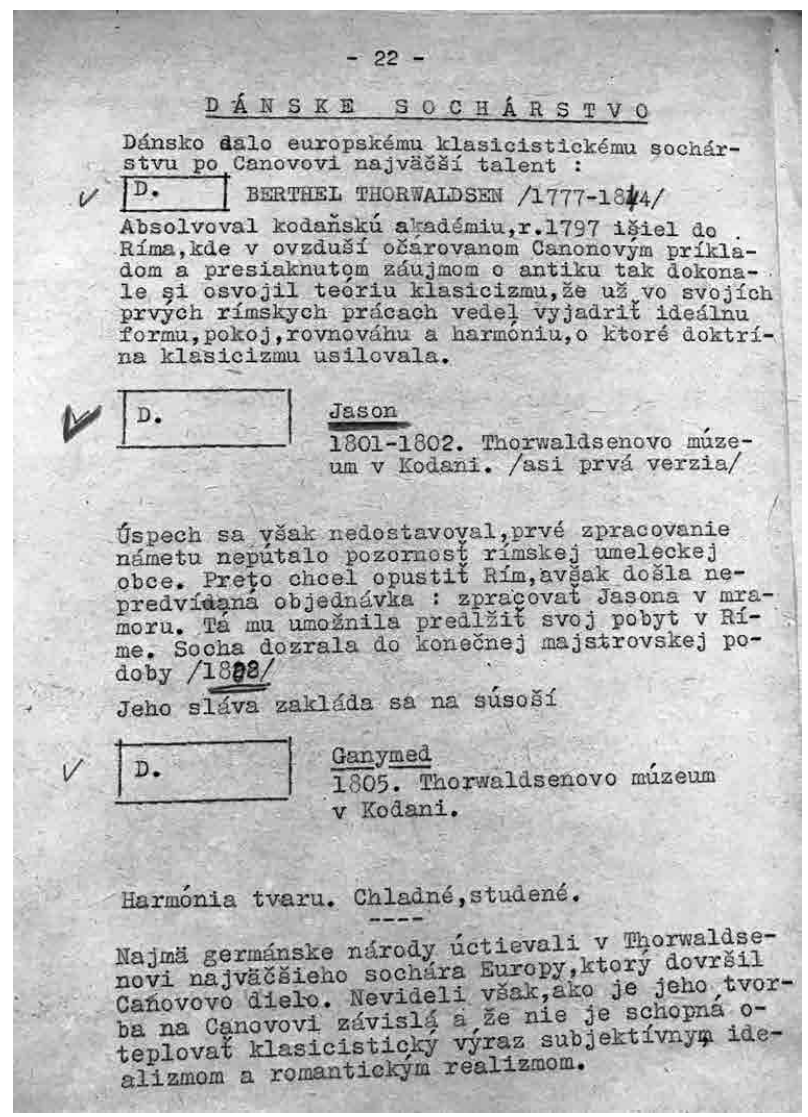

Obr. 11: Ukážka z.prednášky k Umeniu 19. storočia na Slovensku, dánske sochárstvo 19. storočia, rukopis. Foto: Archiv výtvarnébo umenia SNG, Osobný fond V. Tilkovský, 12 G 5.

V osobnom fonde $\mathrm{v}$ SNG sa zachovali celé znenia prednášok, ktoré umožňujú podrobnejšie nazretie do spôsobu Tilkovského pedagogického pôsobenia. Písal si ich na stroji a doplñal ručne písanými osobnými poznámkami (obr. 11). Obrazový materiál poskytovali sklenené diapozitívy, využívané na katedre z Matejčekových dejín umenia. Pre dejiny umenia 19. storočia, ktoré patrilo k jeho špecializácii začínal obdobím od francúzskej revolúcie k empíru, ktoré rozdel'uje podl’a jednotlivých národných škôl.

${ }^{63} \mathrm{O}$ týchto osobnostiach písal i do Výtvarného života - TILKOVSKÝ, V.: V Cézannovom ateliéri. In: Výtvarný život, 2, 1957, č. 2, s. 59-64; Picassovo kreslený denník. In: Výtvarný život, 18, 1973, č. 5, s. 46-47.

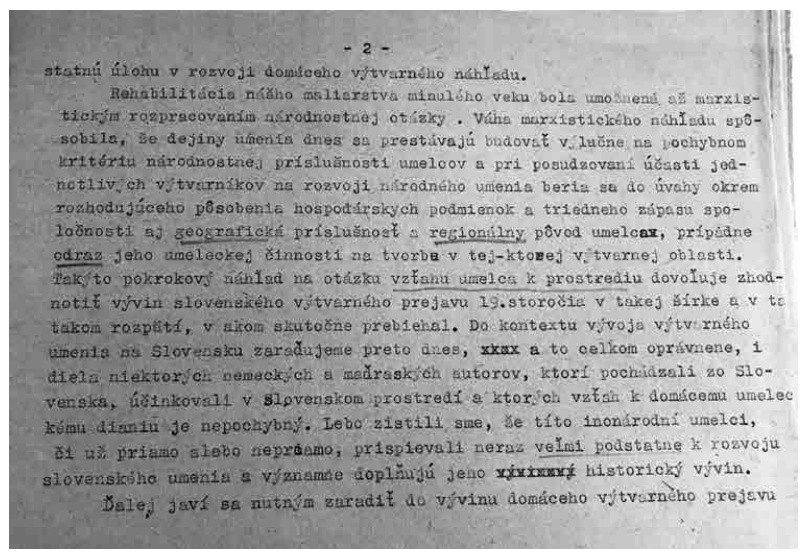

Obr. 12: Ukážka prednášky ke Dejinám 19. storočia na Slovensku, rukopis. Foto: Archiv výtvarnébo umenia SNG, Osobný fond V. Tilkovský, 12 G 2.

Nasleduje doba od viedenského kongresu po rok 1848, realistické umenie a prechod od kapitalizmu do obdobia imperializmu v Európe, kde sa venuje impresionizmu a secesii. Prednášky ukončuje tvorbou Cézanna a kubizmu ako odklonu umenia od skutočnosti. ${ }^{63}$ Mal pripravené aj prednášky k dejinám výtvarného umenia 19. storočia na Slovensku, kde ale v úvode sám konštatuje: „Hovorit’ o slovenskom maliarstve 19. storočia je dnes ešte dost' odvážne lebo doba a výtvarný materiál nie sú ešte historicky prebádané, ani esteticky zhodnotené a to, o co sa teraz pokúšame, podat' preblad vývinu maliarstva na Slovensku v 19. storočí, je viacej námet ke diskusii než vynášanie ujasnených súdov.“64 Ďalej sa vyjadruje k téme geografickej a regionálnej príslušnosti umelca a jeho pôvodu a kladie si otázku vzt'ahu umelca k prostrediu čo ,dovol'uje zhodnotit' vývin slovenskébo výtvarného prejavn 19. storočia v takej sírke a $v$ takom rozpätí, $v$ akom skutočne prebiebal. “65 $\mathrm{S}$ tým súvisí i marxistická metodika: „Rehabilitácia nášbo maliarstva minulého veku bola umožnená až marxistickým rozpracovaním národnostnej otázky." “66 (obr. 12) Používa termíny ako „geografická príslušnost“", ,,regionálny pôvod umelca“, alebo „vzt'ah umelca k prostrediu“.

${ }^{64}$ OF VT, inv. č. 12 G 2 - Písomnosti, 19. stor. na Slov. (maliarstvo).

${ }^{65}$ Ibidem.

${ }^{66}$ Ibidem. 
Preto do kontextu zarad'uje aj umelcov nemeckého a mad'arského pôvodu a uvedomuje si ich prínos pre rozvoj lokálneho umenia. Všíma si aj domácich maliarov, ktorých ale lokálne podmienky usmernili na tvorbu mimo vlasti. Jeho vývin začína preto logicky v zmysle jeho téz J. J. Stunderom, dánskym maliarom činným v Levoči a Banskej Bystrici. Pokračuje J. Czauczikom, J. Rombauerom, J. Ginovským a rodinou Klimkovičovcov, K. Tibelyho. Uvádza aj umelcov činných mimo nášho územia ako K. Marko st., K. L'. Libay, všíma si napríklad dlho opomínaného maliara L. Benického, ale i L. Horovitza a J. Benczúra. K národne orientovaným maliarom patria podl'a neho J. B. Klemens, P. M. Bohúň, A. Belopotocký, J. Pálka. So záverom storočia sa venuje V. Angyalovi, L. Mednyánszkemu, D. Skutezkému, J. Štetkovi, E. Ballovi, L. Pitthordtovi a J. Hanulovi, J. Murgašovi, C. Kutlíkovi a M. T. Mitrovskému, o ktorom napísal aj monografiu v 40. rokoch.

$\mathrm{V}$ d'alšom školskom roku mal podl'a dohody s vedením fakulty prednášat' Svetové umenie 19. storočia, impresionizmus a postimpresionizmus, čo úradník v liste Tilkovskému zapísal ako imperializmus a samostatný predmet bol Picasso a jeho význam pre vývin súčasného umenia. $\mathrm{K}$ týmto dvom posledne menovaným predmetom sa bohužial' nezachovali Tilkovského podklady $\mathrm{k}$ prednáškam. $\mathrm{V}$ letnom semestri mal tie isté hodiny, okrem tej venovanej Picassovi. V školskom roku 1957/58 vyučoval opät' dejiny umenia 19. storočia, čo bol v jeho prípade už zabehnutý predmet a ako dva nové sú uvedené Dejiny uhorského umenia a dejiny mad'arského umenia (obr. 13), všetko v rozsahu 2 hod. do týždňa pre letný semester $1957 / 58 .{ }^{67}$ Začína s prehladom mad'arského dejepisu umenia, kde spomína významné osobnosti z druhej polovice 19. storočia. V školskom roku 1958/59 mal mat' Tilkovský zaradené iné predmety, aké dovtedy prednášal. Podl'a plánu katedry boli zaradené predmety „Metódy slohového rozboru“ pre 3. ročník a „Národné umenie l'udových demokraciî“, ako aj výberové prednášky pre 3. až 5. ročník. ${ }^{68}$ Pravdepodobne z jeho vlastného

\footnotetext{
${ }^{67}$ OF VT, inv. č. 12 A 10, Korešpondencia, Dekanstvo FiF UK, 28. 2. 1958.

${ }^{68}$ KOLBIARZ CHMELINOVÁ 2019, c. d. (v pozn. 59), s. 180,
}

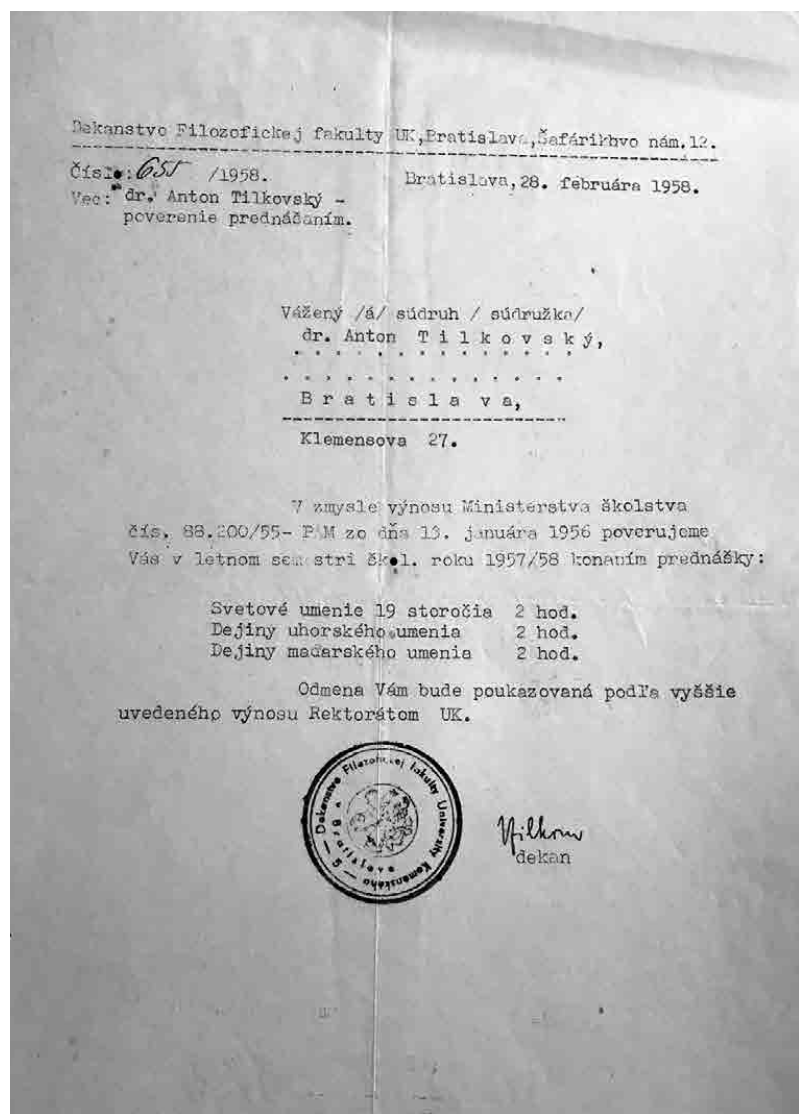

Obr. 13: List z. Dekanátu Filozofickej fakulty Slovenskej univerzity $v$ Bratislave, 28. február 1958. Foto: Archív výtvarnébo umenia SNG, Osobný fond V. Tilkouský, 12 A 10.

rozhodnutia ako i z postupne nie priaznivej podpory pre jeho uplatnenie sa $\mathrm{v}$ Bratislave bol nakoniec z tohto školského roka vyškrtnutý a jeho plánovaný úväzok v počte 4 hodiny do týždňa sa neuplatnil. V osobnom fonde Tilkovského $\mathrm{v}$ archíve výtvarného umenia SNG je zachovaný obal s prednáškami, ktoré mal pripravené pre Univerzitu Komenského. Okrem tých, ktoré podl’a svojho úväzku v rokoch 1955-1958 realizoval, mal pripravené i texty ku Krest'anskej antike a Filozofii renesancie a humanizmu. ${ }^{69}$

repr. 8. - Plán prednášok dejín umenia na UK pre školský rok 1958/59.

${ }^{69}$ OF VT, inv. č. 12 G 4, Písomnosti - Krest'anská antika; 12 G 3 - Filozofia renesancie a humanizmu. 


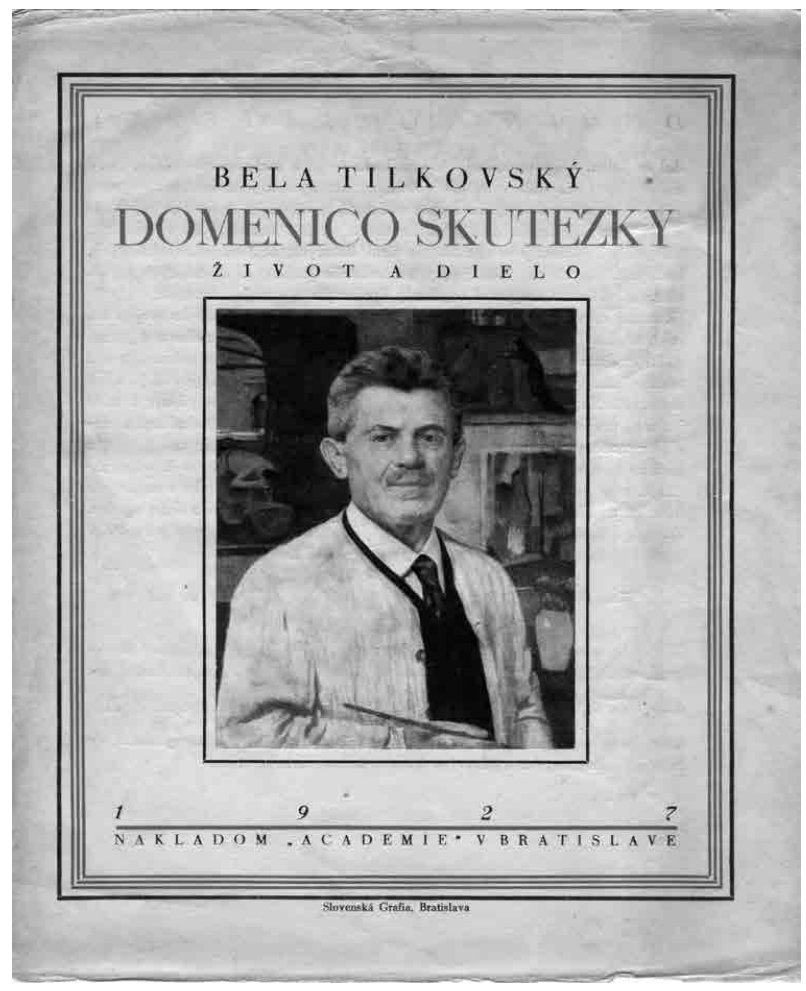

Obr. 14: Obálka pripravovanej kniby o Skutezkom, okolo 1927. Foto: Archiv výtvarnébo umenia SNG, Osobný fond $V$. Tilkovský, apendix.

Tilkovský vel’mi dobre vychádzal s vtedajšími pedagógmi katedry, predovšetkým s Wagnerom a Güntherovou. I ked' dokladov nie je zachovaných vel'a, ich listy odkazujú na vel'mi osobný záujem o jednotlivé udalosti v živote Tilkovského. V roku 1950 zomrela jeho matka, na ktorú spomína v liste z Betliara Güntherová, ${ }^{70}$ ktorá o tejto udalosti počas návštevy oboznámila aj Wagnera. Josef Vydra vel'mi odporúčal Tilkovského ako nástupcu Wagnera, ktorý zastával tri miesta - pracoval na univerzite, pamiat-

\footnotetext{
${ }^{70}$ OF VT, inv. č. 12 A 73, Korešpondencia, Alžbeta Güntherová-Mayerová, 25. 7. 1950, Betliar.

${ }^{71}$ OF VT, inv. č. 12 A 83, Korešpondencia, Jozef Vydra, 1949.

${ }^{72}$ Spomienky absolventov a pedagógov dejín umenia na UK v Bratislave, In: KOLBIARZ CHMELINOVÁ - BEŇOVÁ 2018, c. d. (v pozn. 59), s. 12, 14.

${ }^{73}$ Ibidem, s. 14.
}

kovom úrade a pre pedagogickú fakultu. Ako píše ešte v roku 1949: „Nejradeji by vás vidèl prof. Kostka na misto dr. Wagnera, který sám nemůže stačit tri funkce... je velice pro Vás a má ten nábled, že se musite vrátit na Slovensko, kam je potreba tolik lidí, a kde není vlastnè nikoho na ty úkoly, které se žádaji. "“71 Obraz o jeho pôsobení si môžeme spravit' na základe spomienok jeho študentov. Napríklad Kahoun a jeho manželka Denisa Kahounová, ktorí v tom čase študovali, si spomínajú: „Celý prehlad nás na úvod učil Vladimír Wagner, neskôr umenie 19. storočia prevąal Vojtech Tilkovsky. Na katedre bola vtedy čerstvo vydatá Elena Dubnická (za slobodna Šterbová). Odpisala Václava Mencla, ktorý bol na malý externý úväzok a skončil v školskom roku 1953/54. Externe bol Tilkouský, externistom bol aj Karol Vaculik. Z Betliara dochádzala Aľ̌beta Güntherová-Mayerová, ktorá nás učila základ a spolu s Menclom sa venovala prebliadom dejin umenia. "72 „Tilkouský nás okrem umenia 19. storočia učil aj umenie 20. storočia, ktoré "lepili" spolu s Radislavom Matuśtíkom. “73 $\mathrm{Na}$ závan západného zmýšl’ania si rozpomína Mária Pötzl Malíková, ktorá hodnotila jeho prednáška nasledovne: „Vojtech Tilkovský, Slovák, žjúciv Prahe, strávil nejaký čas na Západe a prinášal nádych elegancie bohémskeho života v Parízi s črtami satirickébo kriticizmu. ${ }^{\text {c74 }}$

\section{Tilkovský a Dominik Skutezky (Skutecký)}

S Univerzitou Komenského je spojený aj Tilkovského celoživotný výskum k osobnosti maliara Dominika Skutezkého. Jeho záujem sa datuje do obdobia jeho štúdií u prof. Žákavca, ktorý mu túto osobnost' odporučil na spracovanie. Bohužial' diplomová práca, ktorú obhájil, je stratená. Dokonca plánoval túto svoju prácu vydat' vo forme monografie, ktorá bola naplánovaná na rok 1927 (obr. 14). Zachovala sa len reklama so zámerom získania financií na jej vydanie. ${ }^{75}$ Malo ju vydat' vydavatel'stvo Academia,

${ }^{74}$ Osobný rozhovor s M. Pötzl Malíkovou, 22. 8. 2018. Rukopis rozhovoru je v archíve Katedry dejín výtvarného umenia UK.

${ }^{75} \mathrm{~V}$ personálnej biografii maliara, ktorú spracovali HRÚZOVÁ, M. - NÉMETHOVÁ, M. - MYSLIVCOVÁ, Z.: Dominik Skutecký (1849 - 1921). Personálna bibliografia. Štátna vedecká knižnica v Banskej Bystrici, Banská Bystrica 2001, sa uvádza vydanie monografie v roku 1927. 
ktoré sídlilo na Grösslingovej ulici v Bratislave. ${ }^{76}$ Reklamný leták bol už graficky upravený s obálkou, ako aj stručnou anotáciou. Pravdepodone neboli nakoniec získané všetky finančné prostriedky a tým pádom nedošlo $\mathrm{k}$ vydaniu alebo vyšla práca len vo vel'mi malom náklade je otázkou ešte d'alšieho bádania. V predvojnovom období navštevoval Tilkovský opätovne prednášky na Filozofickej fakulte UK u prof. Eugena Dostála a v júni 1939 zložil rigoróznu skúšku so svojou dizertačnou prácou na tému života a diela Skutezkého. Získal titul doktora filozofie $z$ odboru dejín umenia. $\mathrm{V}$ archívnom fonde výtvarného umenia v SNG sa nachádza kópia tejto práce, ktorú si Tilkovský odkladal. Ďalší pokus o publikovanie súvisí s Vydavatel'stvom Pokrok, ktoré sídlilo na Laurinskej ul. $7 \mathrm{v}$ Bratislave a v roku 1946 zamýšl’alo vydat' Skutezkého monografiu. Ako sa píše v zachovanom liste $\mathrm{z}$ vydavatel'stva z 14 . februára 1946 ,podl'a našej dnešnej dohody sme ochotní vydat' našim nákladom vašu knibu „Domenico Skuterky, doba, řivot a dielo ", ktorej pôvodný rukopis sme cítali a k.torý prepracujete a upravite podl'a potreby, aby yyhovel dnešnej dobe a knižnému vydaniu. ${ }^{677}$

Nakoniec sa podarilo knihy vydat' až niekol'ko rokov po vojne vo vydavatel'stve Tvar. Ako autor spomína „Začal som znovu pátrat’ po Skutezkébo obrazoch a po niekol'koročnej sústavnej a často dobrodružnej práci podarilo sa mi na základe svojich staryích záznamov a fotografii, a zo zlomkov jeho životnej tvorby, ktoré sa medzi časom yynorili, zostavit' materiál pre jeho monografiu, k.torá vyšla v roku 1954 so súpisom 326 autentických diel." ${ }^{\text {"78 }}$ Tilkovský mal vel'kú výhodu, že ešte v medzivojnovom období chodieval do Banskej Bystrice a mal možnost' sa stretnút' s manželkou Dominika Skutezkého. $\mathrm{V}$ tom čase sa $\mathrm{v}$ umelcovej vile nachádzali diela aj korešpondencia a archív. To sa ukázalo ako vel'mi dôležité pri vydaní práce v roku 1954, ked’že rodinu Skutezkých a Karvašovcov postihli represie druhej svetovej vojny. „Táto štúdia je pryým pokusom o monografické spracovanie života a diela maliara na základe údajov v druhej polovici dvadsiatych rokov tohto storočia, teda krátko po umelcovej smrti, ked' jeho ateliér bol ešte

\footnotetext{
${ }^{76}$ Za informáciu d’akujem Kataríne Baraníkovej zo Stredoslovenskej galérie v Banskej Bystrici.

77 OF VT, inv. č. 12 A 25 - Korešpondencia, Pokrok, list z 14. 2. 1946.
}

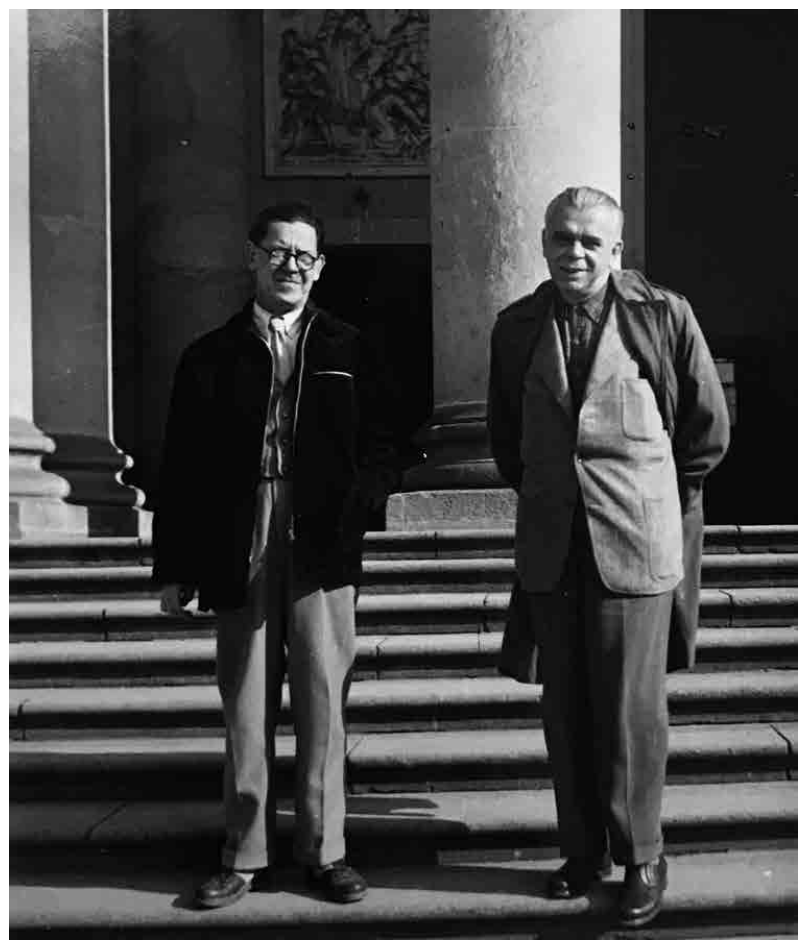

Obr. 15: Vojtech Tilkovský, okolo 1960-1970. Foto: Archiv výtvarnébo umenia SNG, Osobný fond $V$. Tilkovský, apendix.

nedotknutý, ked' jeho obrazy boli ešte v rukách pôvodných majitel'ov a pamiatka jeho osobnosti a osudov bola ešte živá. “79 Tilkovský si uvedomoval, že hlavne obdobie viedenského a benátskeho obdobia nevie dostatočne interpretovat' na jednej strane kvôli absencii známeho výtvarného materiálu a zároveň i kvôli nemožnost' vycestovat' po vojne na západ, kde mohol svoj výskum rozvinút'. Skutezkého tvorba bola propagovaná autorom monografie aj na stránkach Kultúrneho života, ktorý ho požiadal o príspevok. ${ }^{80}$ Zachovali sa posudky recenzentov, napríklad list od Karvaša, v ktorom píše o celkovom dojme z knihy, ktorý hodnotí ako vel'mi priaznivý. Druhý recenzent bol Váross, ktorý sa napríklad vyjadril: „Zdá sa mi, že $v$ niektorých pripadoch sa dost' mechanicky bl'adajú závislosti

\footnotetext{
${ }^{78} \mathrm{OF}$ VT, inv. č. $12 \mathrm{C} 7$.

79 TILKOVSKÝ 1954, c. d. (v pozn. 1), s. 9.

${ }^{80}$ OF VT, inv. č. 12 A 16 - Korešpondencia, Kultúrny život.
} 
Skuteckého tvorby od spoločensko-hospodárskych pomerov. $\mathrm{Na}$ konkrétne priklady poukážem autorovi v osobnom rozbovore. V niektorých partiách textu nevystupujúv v dost' jasných süvislostiach terminy naturalizmus, realizmus, impresionizmus a pod." ${ }^{181}$ Tretím recenzentom bol Vaculík, ktorý oceňuje dlhoročnú znalost' materiálu, ktorý Tilkovský spracováva. ${ }^{82}$

\section{Tilkovský vo svetle slovenských dejín umenia}

Na začiatku svojho štúdia bol Tilkovský (obr. 15) pre sympatie s pokrokovými politickými myšlienkami prenasledovaný horthyovskou políciou a internovaný v Ostrihome. ${ }^{83}$ Po vzniku Československej republiky vyštudoval ekonómiu a primárne dejiny umenia, ktoré sa stali jeho celoživotným predmetom záujmu. Počas svojho života bol publikačne činný, sám uvádza stovky článkov, kritík, úvodov do katalógov, články nachádzame v časopisoch Forum, Výtvarné umenie, Výtvarná práca, Tvar a i mad’arských $A$ Reggel, $A$ Hét a d'alšie. Túto jeho činorodost' pripomína i jeho priatel’ a kolega Július Kálman - „Ako vidno z. tvojho listu, mraky sa Tvojej cinorodosti nedotkli, co len poturd₹uje Tvoju búřevnatost."“84

Predmetom tohto príspevku je nielen ozrejmenie životného osudu historika umenia Vojtecha Tilkovského, ale predovšetkým jeho pôsobenie na Univerzite Komenského. Potom, ako sa stal jedným z prvých absolventov prof. Žákavca, sa pokúsil získat' uplatnenie ako pedagóg $\mathrm{v}$ priebehu 50. rokov 20. storočia. Nakoniec sa stal len externistom. I ked' bol Pavicového zmýšl’ania a vedel sa adaptovat' na zložitú situáciu po roku 1948, situácia na Katedre vied o umení nebola jednoduchá. Nie je zatial' známe, prečo nakoniec nebolo pre Tilkovského možné, aby sa stal riadnym členom katedry. Jeho prednášky boli kvalitné, kde využíval i svoje znalosti z odbornej praxe. Potom ako mu nebolo umožnené sa stat' ani pracovníkom SNG, akadémie vied a nakoniec i univerzity sa nakoniec rozhodol vrátit' natrvalo do Prahy, kde žila jeho rodina a odkial' dochádzal za svojimi povinnost'ami do Bratislavy. Stal sa členom redakcie časopisu Umèní a Řemesla, ktorý i počas obdobia totality patril k tým otvorenejším platformám. Ako uvádza v Tilkovského nekrológu Július Kálman „Na vysokej, typograficky pruə̌nej úrovni tejto revue bolo vidiet' iniciativu séfredaktora v nápaditosti úpravy a v pedantnom, adekvátnom hodnoteni artefaktov ludovej umeleckej výroby i umeleckých remesiel." ${ }^{45}$ Jeho kontakty zo Slovenskom i po tomto období nad’alej boli dobré, publikoval občasne vo Výtvarnom živote a v priebehu 70. rokoch nadviazal kontakt s Banskou Bystricou, kvôli prednáškam o Skutezkom a dokonca i so svojim rodiskom, Levočou. V roku 1971 ho napríklad oslovila komisia na čele s dr. Chalupeckým, aby sa podielal na kapitole Gotické sochárstvo v Levoči do konca 15. storočia, ktorá sa mala stat' súčast’ou I. zväzku kultúrnych dejín Levoče. ${ }^{86}$

\footnotetext{
${ }^{81} \mathrm{OF}$ VT, inv. č. 12 E 2 - posudky.

${ }^{82}$ Ibidem.

${ }^{83}$ http://madari.sk/publikacie/gabor-hushegyi-vytvarne-umenie-fotografia-a-architektura
}

\footnotetext{
${ }^{84}$ OF VT, inv. č. 12 D 3 - Písomnosti, Dominik Skutecký.

${ }^{85}$ KÁLMAN, 1978 c. d. (v pozn. 3), s. 7.

${ }^{86}$ OF VT, inv. č. 12 A 21 - Korešpondencia, MsNV v Levoči.
} 


\title{
Art Historian Vojtech Tilkovský (1902 - 1978) and His Activities at Comenius University
}

\author{
Résumé
}

Vojtech (Béla) Tilkovský, the art historian, art critic, radio editor and journalist, is not well known among art historians. He was born in 1902 in Levoča, then still part of the Austro-Hungarian Monarchy, and died in 1978 in Prague. In 1922 he began to study international commerce in Vienna and attended art history professors Max Dvořák and Josef Strzygowski at Vienna University. After the art history seminar at the Philosophical Faculty of Comenius University was introduced in 1924, Tilkovský returned to Bratislava and became a student of František Žákavec, whom he highly respected. He studied art history there from 1924 to 1927, and in the 1950s, he was hired as a part-time lecturer. For most of his career, he worked in Bratislava and Prague before permanently settling in the Czech metropolis in the late 1950s. His primary research focused on painter Dominik Skutezky (Skutecký), about whom he wrote his masters' thesis and dissertation, and in 1954 his monograph.

After graduating with a degree in art history, he worked as a radio editor/journalist for broadcasting in the Hungarian language and as the Litevna Publishing House manager from 1929 to 1932. He also worked for the newspaper $A$ reggel and was a regular contributor to the journals and newspapers $D A V$, Slovensky dennik and many others. As a scholarship holder, Tilkovský was granted a scholarship to do an internship in Paris in 1928 - 29. He also attended the lectures of professors René Schneider and Henri Focillon at the Sorbonne. He also took trips to Switzerland in 1930, Yugoslavia, Albania, Greece in 1936, Latvia, Estonia, and Finland in 1938. At Comenius University, he attended lectures of professor Eugen Dostál, and in 1939 he passed his doctoral exam. His work was again focused on Skutezký. During the years of the Slovak State, he was the head of various departments at Slovak Radio, particularly the foreign news department. He was also the author of the following books: Výtvarná pozostalost' $M$. Th.
Mitrouskébo (The Fine Art Estate of M.Th. Mitrouský 1943), and Mudroch (1944). After WWII, he moved to Prague, where he was appointed expert advisor at the Ministry of Industry responsible for the creative industry. In Bratislava, he worked for the TVAR Publishing House and a short period, and he was editor-in-chief of the journal Výtvarny život (Fine Art Life, 1957). He tried to find an expert position at various institutions, including the newly founded Slovak National Gallery, but without success.

Tilkovský also sought out teaching positions. After several attempts at the Slovak School of Technology in 1955, he became a part-time lecturer of art history at his alma mater (Comenius University). Tilkovský's field of expertise was the art history of the $19^{\text {th }}$ century for $4^{\text {th }}$-year students, for which he prepared thirty 2-hour lectures. The full texts of his lectures were preserved in his archives at the Slovak National Gallery, which provides a more detailed look at his pedagogical activities. He typed them and later added handwritten comments and notes in the margins. He used the glass slides from Antonin Matejček's book entitled Art History in Pictures as visual material. Although his material was based on Marxist aesthetics, he complemented his lectures with extensive knowledge, which his students remembered well. In the 1956/57 academic year, he again taught art history of the $19^{\text {th }}$ century, which in his case was a well-established course. Two new methods were mentioned - History of Hungarian Art and History of Magyar Art, all of which were 2-hour classes that met once a week for the summer semester. According to the department plans, the courses entitled Methods of Style Analysis for $3^{\text {rd }}$-year students and the National Art of People's Democracies as an elective lecture for $3^{\text {rd }}$ to $5^{\text {th }}$-year students were included in the course list for the 1958/59 academic year. Most probably of his own accord, but also due to the gradually deteriorating support for his employment in Bratislava, his name 
was crossed off the list of teachers. The courses that he was assigned to teach were not opened.

A folder with other lectures prepared for Comenius University has been preserved in Tilkovský's personal archives within the Slovak National Gallery's archives. In addition to hours, which according to his workload for the 1955-1958 academic year he lectured, he prepared texts for Christian Antiquity and Philosophy of Renaissance and Humanism; he also planned to focus on the history of the fine art of the $19^{\text {th }}$ century in Slovakia. Tilkovský taught at Come- nius University until 1958, after which he moved to Prague where he permanently settled with his family and worked as a publicist and editor-in-chief of the journal Uméni a remesla (Arts and Crafts). His art research of the $19^{\text {th }}$ century was interrupted several times, first by the Slovak State, the defence of his position within this state and subsequently by the change in the political situation in 1948. Although he could not publish continuously, his publishing activities in Slovakia, Czechia and Hungary are relatively abundant and essential for this period. 